\title{
Review of Thermophysical Property Data of Octadecane for Phase-Change Studies
}

\author{
Moritz Faden ${ }^{1, *}$, Stephan Höhlein ${ }^{1}{ }^{\circledR}$, Joschka Wanner ${ }^{2}{ }^{\circledR}$, Andreas König-Haagen ${ }^{1}$ and \\ Dieter Brüggemann ${ }^{1}$ \\ 1 Chair of Engineering Thermodynamics and Transport Processes (LTTT), Center of Energy Technology (ZET), \\ University of Bayreuth, Universitätsstraße 30, 95440 Bayreuth, Germany; \\ Stephan.Hoehlein@uni-bayreuth.de (S.H.); Andreas.Koenig-Haagen@uni-bayreuth.de (A.K.-H.); \\ Brueggemann@uni-bayreuth.de (D.B.) \\ 2 Chair of Empirical Economics, University of Bayreuth, Universitätsstraße 30, 95440 Bayreuth, Germany; \\ Joschka.Wanner@uni-bayreuth.de \\ * Correspondence: LTTT@uni-bayreuth.de; Tel.: +49-921-55-7161
}

Received: 19 August 2019 ; Accepted: 10 September 2019; Published: 14 September 2019

check for updates

\begin{abstract}
In this work we derive temperature-dependent functions for the most important material properties needed for phase change studies with octadecane. Over 80 references are reviewed in which at least one thermophysical property of octadecane is measured. The functions are valid $\pm 40 \mathrm{~K}$ around the melting temperature and are surrounded by their confidence interval. It turns out that the values for the solid phase have much broader confidence intervals than the ones of the liquid phase. Hence, more accurate measurements are particularly desirable for the solid state material properties.
\end{abstract}

Keywords: PCM; melting point; latent heat of fusion; density; thermal conductivity; heat capacity; viscosity

\section{Introduction}

The rising $\mathrm{CO}_{2}$ concentration in the atmosphere and the looming climate change have led to a mentality change in power and heat supply, away from fossil fuels to regenerative sources. The most regenerative sources, however, have the disadvantage of fluctuations. Therefore energy storage systems, which are e.g., based on thermal, electrochemical or mechanical effects, are necessary for a reliable energy supply. One important subclass of thermal storage systems are latent heat thermal energy systems, which mostly use the solid-liquid phase transition of a phase change material (PCM) to store thermal energy at a nearly constant temperature. The dimensioning of such systems is mainly done with semi-empirical or numerical methods which need the thermophysical properties of the PCM as an input paramenter. Often these methods are insufficiently validated. This is due to the lack of reliable validation experiments and the strong scatter of available literature values for one and the same thermophysical property.

There are a lot of different PCMs available on the market, but octadecane $\left(\mathrm{C}_{18} \mathrm{H}_{38}\right)$ is one of the most studied PCM and is often used for validation experiments [1-4]. Frequently mentioned reasons for this are the melting temperature close to the ambient conditions, a translucent liquid phase, cycle stability and apparently well-known thermophysical properties [5]. Nevertheless, the thermophysical properties of octadecane given in the literature vary greatly, especially close to the melting temperature and in the solid phase. The reason for this is that paraffins were first studied in the petrochemical industry [6], i.e., at higher temperatures where the paraffins are liquid and that measuring close to or across a phase transition is far from trivial $[7,8]$. Near the melting point, the change in the thermophysical properties is very rapid and not all measuring methods can cope with this additional difficulty. A complete literature review including the measuring methods will be given in Section 2. 
Obviously, the uncertainty in the input parameters, i.e., the thermophysical properties, propagates through the empirical or numerical model [9] and makes it hard to distinguish between numerical errors, modelling errors and errors due to wrong input parameters. This makes validation more difficult and reduces its usefulness.

In the late 90s Bertrand et al. [10] compared numerical methods for liquid-solid phase change methods and utilised rather crude thermophysical properties for octadecane. Although it is certainly useful to check for numerical errors by applying standardized thermophysical properties, no later than during the validation of the numerical model with experiments the best possible approximation of the real thermophysical properties of the involved PCM are needed [11]. Sometimes missing properties are supplemented with data from similar materials. For example Kozak and Ziskind [12] took the, also uncertain, thermophysical properties of eicosane and applied them to octadecane - although they differ in the single digit percentage range.

Another issue is that the majority of authors neglect the density change during melting and use the Boussinesq approximation to model natural convection, despite the fact that there are methods for solving melting or solidification with volume change [13,14]. In addition, many authors assume temperature-independent properties, although they can vary quite strongly, e.g., the viscosity. Maybe this is because the influence of the thermophysical properties is underestimated. Tan et al. [15] and Madruga and Curbelo [16] investigate the complex spatio-temporal behaviour of solid-liquid phase change coupled with fluid flow, whereas the former assume a constant thermophysical property value regardless of the phase and the latter distinguish between constant values in the solid and liquid phase. A positive exception is Galione et al. [17], who simulate the melting of octadecane with temperature-dependent values for most properties. To do so, they derive linear functions, but the selection of the raw data is arbitrary and only one reference per property is used to derive the function.

The aim of this study is to reduce the uncertainty about the thermophysical properties of octadecane and relief the modeler of a cumbersome literature review. Based on a comprehensive review of data available in the literature and own measurements, we provide estimates for the melting temperature and enthalpy, as well as for the relationships between temperature and thermal conductivity, heat capacity, density and viscosity. These are the most relevant thermophysical properties to simulate melting and/or solidification processes. Another important parameter is the volumetric coefficient of thermal expansion, which can be derived from the determined density curves and is therefore not considered separately. In addition, uncertainty bounds for each property are specified by means of statistical methods applied to the raw data of the literature.

\section{Literature Review of Thermophysical Properties of Octadecane}

This section provides an overview of the available literature data on the thermophysical properties of octadecane. If not available, the uncertainties required for the statistical evaluation are estimated from the applied measurement methods.

\subsection{Melting Temperature}

There are numerous results for the melting temperature of octadecane available in the literature. A lot of these results were achieved from the heat flow signal of differential scanning calorimetry (DSC) measurements but without giving information about the way of determining this temperature. Höhne et al. [18] describe five characteristic temperatures of the heat flow signal of a melting process which are the initial peak temperature $T_{i}$, the extrapolated onset temperature $T_{e}$, the peak maximum temperature $T_{p}$, the extrapolated offset temperature $T_{c}$ and the final peak temperature $T_{f}$. The difference between these temperatures depends on the sample and test parameters (thermal conductivity, mass, heating rate). This can be one reason for the huge spread of several kelvin of the melting point results which can not be explained by the uncertainty of temperature calibration or different sample purities. Only the extrapolated peak onset temperature $T_{e}$ is relatively independent of the above mentioned parameters and is therefore recommended to be used to characterize phase transitions [18]. 
The melting temperature results are categorized in accordance with the above mentioned temperature definitions. Temperatures which are not unambiguously defined in the research papers are either defined as temperature $T_{*}$ or, if possible, categorized based on the evaluation of the given heat flow signals. Qiu et al. [19] and Li et al. [20] have determined $T_{i}$ for the melting peak of octadecane. The majority of researchers have defined $T_{e}[21-31]$ or $T_{p}[19,20,29,31-41]$ as the melting temperature. Temperatures $T_{*}$ with insufficient information about their determination have been reported for DSC measurements [42-51], for adiabatic calorimeters (AC) [52-55] and for results which have been achieved with other not classified (NC) techniques [6,56-62]. A summary of all available data on the melting temperature can be found in Table 1 (alongside with data on the enthalpy, described in the next section) and Figure 1a which shows the melting temperatures arranged according to the given temperature definitions and its mean values.

Table 1. Summary of melting temperature and enthalpy data from the literature.

\begin{tabular}{|c|c|c|c|c|c|c|c|}
\hline Reference & $\begin{array}{c}\text { Purity } \\
\text { in \% }\end{array}$ & Year & Method & $\begin{array}{c}\text { Temperature } \\
\text { in } K\end{array}$ & $\begin{array}{l}\text { Uncert. } \\
\text { in } K\end{array}$ & $\begin{array}{l}\text { Enthalpy } \\
\text { in } J / g\end{array}$ & $\begin{array}{c}\text { Uncert. } \\
\text { in \% }\end{array}$ \\
\hline Rossini [6] & $\mathrm{n} / \mathrm{a}$ & 1952 & $\mathrm{NC}$ & $T_{*}=301.34$ & 0.02 & 243.6 & 0.3 \\
\hline Qiu et al. [19] & 99 & 2012 & $\mathrm{DSC}, 5 \mathrm{~K} / \mathrm{min}$ & $\begin{array}{l}T_{i}=298.65 \\
T_{p}=301.55 \\
T_{f}=303.65\end{array}$ & $\begin{array}{l}\mathrm{n} / \mathrm{a} \\
\mathrm{n} / \mathrm{a} \\
\mathrm{n} / \mathrm{a}\end{array}$ & 223.1 & $\mathrm{n} / \mathrm{a}$ \\
\hline Li et al. [20] & 99 & 2011 & $\mathrm{DSC}, 10 \mathrm{~K} / \mathrm{min}$ & $\begin{array}{l}T_{i}=298.36 \\
T_{p}=302.97\end{array}$ & $\begin{array}{l}\mathrm{n} / \mathrm{a} \\
\mathrm{n} / \mathrm{a}\end{array}$ & 235.9 & $\mathrm{n} / \mathrm{a}$ \\
\hline Tang et al. [21] & 97 & 2017 & $\mathrm{DSC}, 5 \mathrm{~K} / \mathrm{min}$ & $T_{e}=301.68^{a}$ & 0.2 & 239.32 & 5 \\
\hline Bayramoglu [22] & 100 & 2011 & $\mathrm{DSC}, 10 \mathrm{~K} / \mathrm{min}$ & $T_{e}=301.11^{a}$ & $\mathrm{n} / \mathrm{a}$ & 239.89 & $\mathrm{n} / \mathrm{a}$ \\
\hline Jeong et al. [23] & $\mathrm{n} / \mathrm{a}$ & 2013 & $\mathrm{DSC}, 5 \mathrm{~K} / \mathrm{min}$ & $T_{e}=303.55$ & $\mathrm{n} / \mathrm{a}$ & $247.6^{b}$ & $\mathrm{n} / \mathrm{a}$ \\
\hline Zhang et al. [24] & $\mathrm{n} / \mathrm{a}$ & 2013 & $\mathrm{DSC}, 5 \mathrm{~K} / \mathrm{min}$ & $T_{e}=299.99^{a}$ & $\mathrm{n} / \mathrm{a}$ & 207.2 & $\mathrm{n} / \mathrm{a}$ \\
\hline Sun et al. [25] & $\mathrm{n} / \mathrm{a}$ & 2013 & $\mathrm{DSC}, 10 \mathrm{~K} / \mathrm{min}$ & $T_{e}=301.04$ & $\mathrm{n} / \mathrm{a}$ & 218.8 & $\mathrm{n} / \mathrm{a}$ \\
\hline Wang and Lu [26] & 99 & 2013 & DSC, $0.5-1.5 \mathrm{~K} / \mathrm{min}$ & $T_{e}=301.55$ & $\mathrm{n} / \mathrm{a}$ & 230.5 & $\mathrm{n} / \mathrm{a}$ \\
\hline Vélez et al. [27] & 99 & 2015 & $\mathrm{DSC}, 2 \mathrm{~K} / \mathrm{min}$ & $T_{e}=300.22^{a}$ & 0.095 & 243.68 & 0.04 \\
\hline Ho and Gao [28] & 99.9 & 2009 & $\mathrm{DSC}, 2 \mathrm{~K} / \mathrm{min}$ & $T_{e}=299.65^{a}$ & $\mathrm{n} / \mathrm{a}$ & 243.1 & $\mathrm{n} / \mathrm{a}$ \\
\hline Li et al. [29] & 97 & 2010 & $\mathrm{DSC}, 5 \mathrm{~K} / \mathrm{min}$ & $\begin{array}{c}T_{e}=301.85^{a} \\
T_{p}=303.47\end{array}$ & $\begin{array}{l}0.2 \\
0.2\end{array}$ & 232.49 & 5 \\
\hline Döğüşcü et al. [30] & $\mathrm{n} / \mathrm{a}$ & 2018 & $\mathrm{DSC}, 3 \mathrm{~K} / \mathrm{min}$ & $T_{e}=300.95$ & $\mathrm{n} / \mathrm{a}$ & 226.2 & $\mathrm{n} / \mathrm{a}$ \\
\hline Qiu et al. [31] & 99 & 2015 & $\mathrm{DSC}, 5 \mathrm{~K} / \mathrm{min}$ & $\begin{array}{l}T_{e}=298.65 \\
T_{p}=301.55\end{array}$ & $\begin{array}{l}\mathrm{n} / \mathrm{a} \\
\mathrm{n} / \mathrm{a}\end{array}$ & 227.1 & $\mathrm{n} / \mathrm{a}$ \\
\hline Jeon et al. [32] & $\mathrm{n} / \mathrm{a}$ & 2012 & $\mathrm{DSC}, 5 \mathrm{~K} / \mathrm{min}$ & $T_{p}=302.06^{a}$ & $\mathrm{n} / \mathrm{a}$ & 241.97 & $\mathrm{n} / \mathrm{a}$ \\
\hline Zhang et al. [33] & 99.9 & 2012 & DSC, $0.2 \mathrm{~K} / \mathrm{min}$ & $T_{p}=303.25^{a}$ & $\mathrm{n} / \mathrm{a}$ & 220.4 & $\mathrm{n} / \mathrm{a}$ \\
\hline Shan et al. [34] & 95 & 2009 & $\mathrm{DSC}, 10 \mathrm{~K} / \mathrm{min}$ & $T_{p}=304.15^{a}$ & $\mathrm{n} / \mathrm{a}$ & 222 & $\mathrm{n} / \mathrm{a}$ \\
\hline Chaiyasat et al. [35] & 99.5 & 2012 & $\mathrm{DSC}, 5 \mathrm{~K} / \mathrm{min}$ & $T_{p}=303.15^{a}$ & $\mathrm{n} / \mathrm{a}$ & 241.7 & $\mathrm{n} / \mathrm{a}$ \\
\hline Chung et al. [36] & $\mathrm{n} / \mathrm{a}$ & 2015 & $\mathrm{DSC}, 10 \mathrm{~K} / \mathrm{min}$ & $T_{p}=301.85^{a}$ & $\mathrm{n} / \mathrm{a}$ & 226 & $\mathrm{n} / \mathrm{a}$ \\
\hline He et al. [37] & 90 & 2014 & $\mathrm{DSC}, 10 \mathrm{~K} / \mathrm{min}$ & $T_{p}=301.89^{a}$ & $\mathrm{n} / \mathrm{a}$ & 209.1 & $\mathrm{n} / \mathrm{a}$ \\
\hline Yu et al. [38] & 98.5 & 2014 & $\mathrm{DSC}, 10 \mathrm{~K} / \mathrm{min}$ & $T_{p}=301.89^{a}$ & $\mathrm{n} / \mathrm{a}$ & 209.1 & $\mathrm{n} / \mathrm{a}$ \\
\hline Zhang et al. [39] & 90 & 2012 & $\mathrm{DSC}, 10 \mathrm{~K} / \mathrm{min}$ & $T_{p}=301.25^{a}$ & $\mathrm{n} / \mathrm{a}$ & 212.6 & $\mathrm{n} / \mathrm{a}$ \\
\hline Babich et al. [40] & $\mathrm{n} / \mathrm{a}$ & 1992 & $\mathrm{DSC}, 2 \mathrm{~K} / \mathrm{min}$ & $T_{p}=301.6$ & $\mathrm{n} / \mathrm{a}$ & 200 & $\mathrm{n} / \mathrm{a}$ \\
\hline Zhu et al. [41] & 90 & 2016 & $\mathrm{DSC}, 10 \mathrm{~K} / \mathrm{min}$ & $T_{p}=301.7^{a}$ & $\mathrm{n} / \mathrm{a}$ & 204.4 & 6 \\
\hline Wei et al. [42] & 99 & 2014 & $\mathrm{DSC}, 1 \mathrm{~K} / \mathrm{min}$ & $T_{*}=300.95$ & 0.2 & 242.24 & 1 \\
\hline Chang et al. [43] & 97 & 1983 & $\mathrm{DSC}, 5 \mathrm{~K} / \mathrm{min}$ & $T_{*}=301.1$ & $\mathrm{n} / \mathrm{a}$ & 233.4 & $\mathrm{n} / \mathrm{a}$ \\
\hline Kolesnikov and Syunyaev [44] & $\mathrm{n} / \mathrm{a}$ & 1985 & DSC, 8 and $1 \mathrm{~K} / \mathrm{min}$ & $T_{*}=301.00$ & $\mathrm{n} / \mathrm{a}$ & 238.7 & $\mathrm{n} / \mathrm{a}$ \\
\hline Huang et al. [45] & 99 & 2005 & DSC & $T_{*}=300.83$ & $\mathrm{n} / \mathrm{a}$ & 232.3 & $\mathrm{n} / \mathrm{a}$ \\
\hline
\end{tabular}


Table 1. Cont.

\begin{tabular}{|c|c|c|c|c|c|c|c|}
\hline Reference & $\begin{array}{c}\text { Purity } \\
\text { in } \%\end{array}$ & Year & Method & $\begin{array}{c}\text { Temperature } \\
\text { in } K\end{array}$ & $\begin{array}{c}\text { Uncert. } \\
\text { in K }\end{array}$ & $\begin{array}{l}\text { Enthalpy } \\
\text { in } \mathrm{J} / \mathrm{g}\end{array}$ & $\begin{array}{c}\text { Uncert. } \\
\text { in } \%\end{array}$ \\
\hline Djordjevic and Laub [46] & $\mathrm{n} / \mathrm{a}$ & 1986 & DSC & $T_{*}=301.6$ & $\mathrm{n} / \mathrm{a}$ & & \\
\hline Fonseca et al. [47] & 99.5 & 2014 & DSC, $0.48 \mathrm{~K} / \mathrm{min}$ & $T_{*}=301.46$ & 0.1 & 241.02 & 1 \\
\hline Boudouh et al. [48] & 99 & 2016 & $\mathrm{DSC}, 0.8 \mathrm{~K} / \mathrm{min}$ & $T_{*}=300.3$ & 0.1 & 256.7 & 0.5 \\
\hline Mondieig et al. [49] & 99 & 2004 & DSC, $2 \mathrm{~K} / \mathrm{min}$ & $T_{*}=301.1$ & $\mathrm{n} / \mathrm{a}$ & 236.1 & $\mathrm{n} / \mathrm{a}$ \\
\hline Robles et al. [50] & 99.4 & 1996 & $\mathrm{DSC}, 2 \mathrm{~K} / \mathrm{min}$ & $T_{*}=301.1$ & 0.6 & 235.0 & 7 \\
\hline Wei et al. [51] & 99.5 & 2013 & $\mathrm{DSC}, 1 \mathrm{~K} / \mathrm{min}$ & $T_{*}=300.9$ & 0.2 & 242.2 & 1 \\
\hline Schaerer et al. [52] & 99.9 & 1955 & $\mathrm{AC}$ & $T_{*}=301.35$ & $\mathrm{n} / \mathrm{a}$ & 241.3 & $\mathrm{n} / \mathrm{a}$ \\
\hline Parks et al. [53] & 96 & 1949 & $\mathrm{AC}$ & $T_{*}=301.3$ & $\mathrm{n} / \mathrm{a}$ & 237.8 & $\mathrm{n} / \mathrm{a}$ \\
\hline Messerly et al. [54] & 99.98 & 1967 & $\mathrm{AC}$ & $T_{*}=301.33$ & $\mathrm{n} / \mathrm{a}$ & 242.5 & $\mathrm{n} / \mathrm{a}$ \\
\hline Meyer and Meyer [55] & 99.9 & 1983 & $\mathrm{AC}$ & $T_{*}=301.27$ & $\mathrm{n} / \mathrm{a}$ & 236.5 & $\mathrm{n} / \mathrm{a}$ \\
\hline Ksiażczak [56] & 99.7 & 1989 & $\mathrm{NC}$ & $T_{*}=301.27$ & 0.02 & & \\
\hline Carey and Smith [57] & 97 & 1933 & $\mathrm{NC}$ & $T_{*}=300.85$ & $\mathrm{n} / \mathrm{a}$ & & \\
\hline Domańska et al. [58] & $\mathrm{n} / \mathrm{a}$ & 1999 & $\mathrm{NC}$ & $T_{*}=301.65$ & $\mathrm{n} / \mathrm{a}$ & & \\
\hline Levene et al. [59] & $\mathrm{n} / \mathrm{a}$ & 1915 & $\mathrm{NC}$ & $T_{*}=301.15$ & $\mathrm{n} / \mathrm{a}$ & & \\
\hline Parks et al. [60] & 95 & 1946 & $\mathrm{NC}$ & $T_{*}=300.85$ & $\mathrm{n} / \mathrm{a}$ & & \\
\hline Krafft [61] & $\mathrm{n} / \mathrm{a}$ & 1882 & $\mathrm{NC}$ & $T_{*}=301.15$ & $\mathrm{n} / \mathrm{a}$ & & \\
\hline Seyer et al. [62] & $\mathrm{n} / \mathrm{a}$ & 1944 & $\mathrm{NC}$ & $T_{*}=301.25$ & $\mathrm{n} / \mathrm{a}$ & & \\
\hline
\end{tabular}

${ }^{a}$ Determined from plot; $^{b}$ Between $28-32{ }^{\circ} \mathrm{C}$.
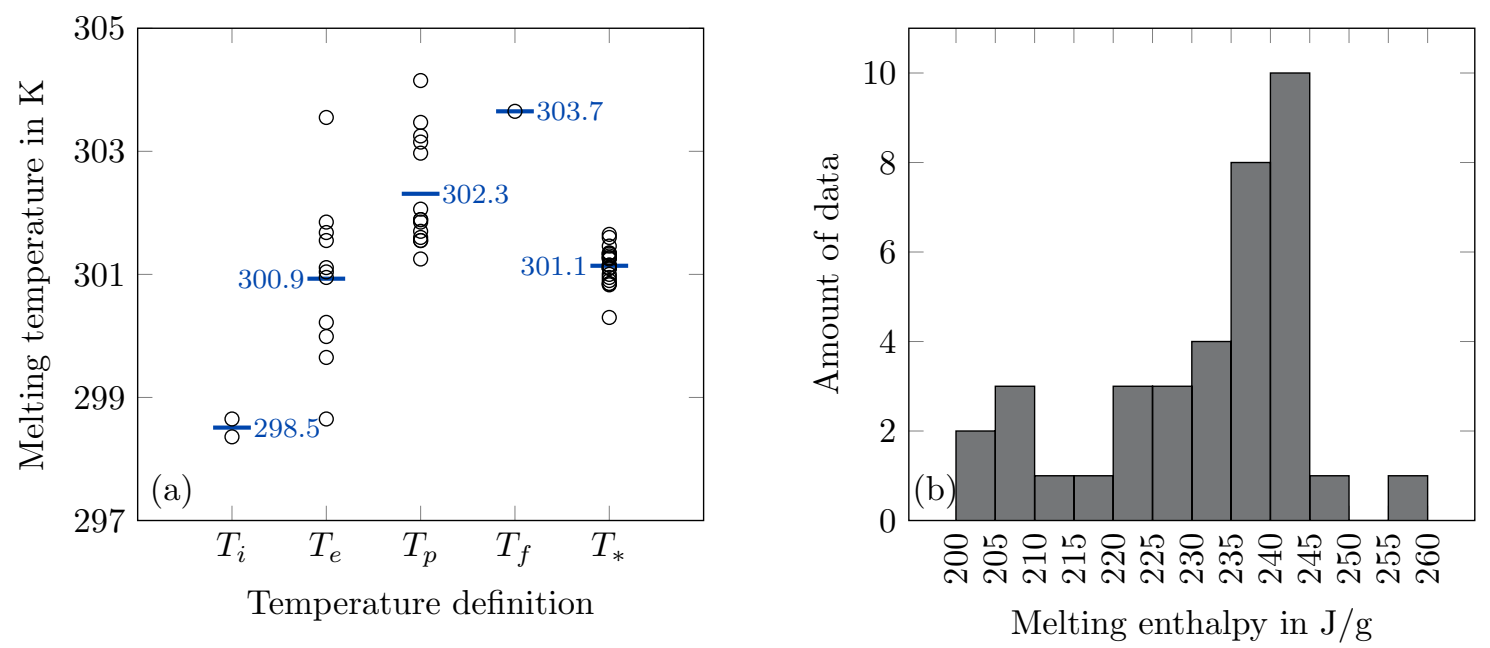

Figure 1. Summary of melting temperature (a) and enthalpy (b) data from the literature. The melting temperature (a) is arranged according to the given temperature definition. The blue bars represent the mean value of the data at each temperature definition. The melting enthalpy data $(\mathbf{b})$ are presented in the histogram according to their frequency.

\subsection{Melting Enthalpy}

As for the melting temperature, there are numerous results for the melting enthalpy of octadecane available in the literature. Many of these results were also obtained from the heat flow signal of DSC measurements, but without giving information about the way of determining the peak area which is the measure for the melting enthalpy [19-45,47-51]. The peak area depends on the integration limits and the type of the assumed baseline of the heat flow signal [18]. Therefore, beside the uncertainty of the measuring instruments itself, one reason for the spread of the melting enthalpy results can be the fact that researchers have applied different evaluation methods. Results achieved from AC have been reported from Schaerer et al. [52], Parks et al. [53], Messerly et al. [54] and Meyer and Meyer [55] and there is no information about the measuring principle for the data of Rossini [6]. A summary of all available data on the melting enthalpy can be found in Table 1 and Figure $1 \mathrm{~b}$ which shows the available melting enthalpy results arranged in a histogram. 


\subsection{Density}

The available results of density measurements can be roughly categorized by the applied measuring principle. Pycnometers (PM) and dilatometers (DM) as independent measuring systems or combinations of both have been applied by the majority of researchers for liquid as well as solid state measurements [62-69]. Liquid state densities have additionally been determined by means of hydrometers (HM) [27,28] and vibrating-element systems (VE) [27,70]. Density measurements based on the method of a hydrostatic weighing (HW) have been performed by Graaf et al. [71] for the liquid state and in the framework of our own research (OR) for the liquid as well as the solid state. Furthermore, there are some publications with experimental results but without specification of the applied measuring principle [6,61,72,73] and the research of Müller and Lonsdale [74], who have applied X-ray measurements which are NC. A summary of all available data on the density can be found in Table 2 and Figure 2.

Table 2. Summary of density data from the literature.

\begin{tabular}{lcccccc}
\hline Reference & $\begin{array}{c}\text { Purity } \\
\text { in \% }\end{array}$ & Year & Method & $\begin{array}{c}\text { Uncertainty } \\
\text { in \% }\end{array}$ & $\begin{array}{c}\text { Observations } \\
\text { Solid }\end{array}$ & Liquid \\
\hline Rossini [6] & $\mathrm{n} / \mathrm{a}$ & 1944 & $\mathrm{NC}$ & 2.5 & 0 & 52 \\
Vélez et al. [27] & 99 & 2015 & $\mathrm{HM} / \mathrm{VE}$ & $1 / 0.01$ & 0 & $10 / 2$ \\
Ho and Gao [28] & 99.9 & 2009 & $\mathrm{HM}$ & 0.07 & 0 & 10 \\
Krafft [61] & $\mathrm{n} / \mathrm{a}$ & 1882 & $\mathrm{NC}$ & $2^{a}$ & 0 & 1 \\
Seyer et al. [62] & $\mathrm{n} / \mathrm{a}$ & 1944 & $\mathrm{DM}$ & $2^{a}$ & 16 & 8 \\
Dover and Hensley [63] & $\mathrm{n} / \mathrm{a}$ & 1934 & $\mathrm{PM}$ & $0.02^{b}$ & 0 & 2 \\
van Hook and Silver [64] & 99 & 1942 & $\mathrm{DM}$ & $2^{a}$ & 1 & 1 \\
Cutler et al. [65] & high purity & 1958 & $\mathrm{DM}$ & 0.1 & 0 & 5 \\
Nelson et al. [66] & $\mathrm{n} / \mathrm{a}$ & 1960 & $\mathrm{DM}$ & $22^{a}$ & 1 & 0 \\
Shlosinger and Bentilla [67] & $\mathrm{n} / \mathrm{a}$ & 1965 & $\mathrm{PM}$ & $2.5(\mathrm{~s}) / 0.26(1)$ & 8 & 6 \\
Findenegg [68] & 99 & 1970 & $\mathrm{PM}$ & 0.02 & 0 & 6 \\
Espeau and Céolin [69] & $\mathrm{n} / \mathrm{a}$ & 2006 & $\mathrm{PM}$ and DM & 1.5 & 0 & 99 \\
Caudwell et al. [70] & 99 & 2004 & $\mathrm{VE}$ & 0.20 & 0 & 7 \\
Graaf et al. [71] & $\mathrm{n} / \mathrm{a}$ & 1992 & $\mathrm{HW}$ & 0.5 & 0 & 10 \\
McKinney [72] & $\mathrm{n} / \mathrm{a}$ & 1923 & $\mathrm{NC}$ & $2^{a}$ & 0 & 1 \\
Würflinger and Schneider [73] & 99 & 1973 & $\mathrm{NC}$ & $2^{a}$ & 1 & 1 \\
Müller and Lonsdale [74] & $\mathrm{n} / \mathrm{a}$ & 1948 & $\mathrm{NC}$ & $2^{a}$ & 1 & 0 \\
Dutour et al. [75] & 99 & 2000 & $\mathrm{VE}$ & $2^{a}$ & 0 & 8 \\
Own research (OR) & 97 & 2018 & $\mathrm{HW}$ & 0.1 & 3 & 3 \\
\hline
\end{tabular}

${ }^{a}$ Assumption, ${ }^{b}$ Assumed value from Findenegg [68].
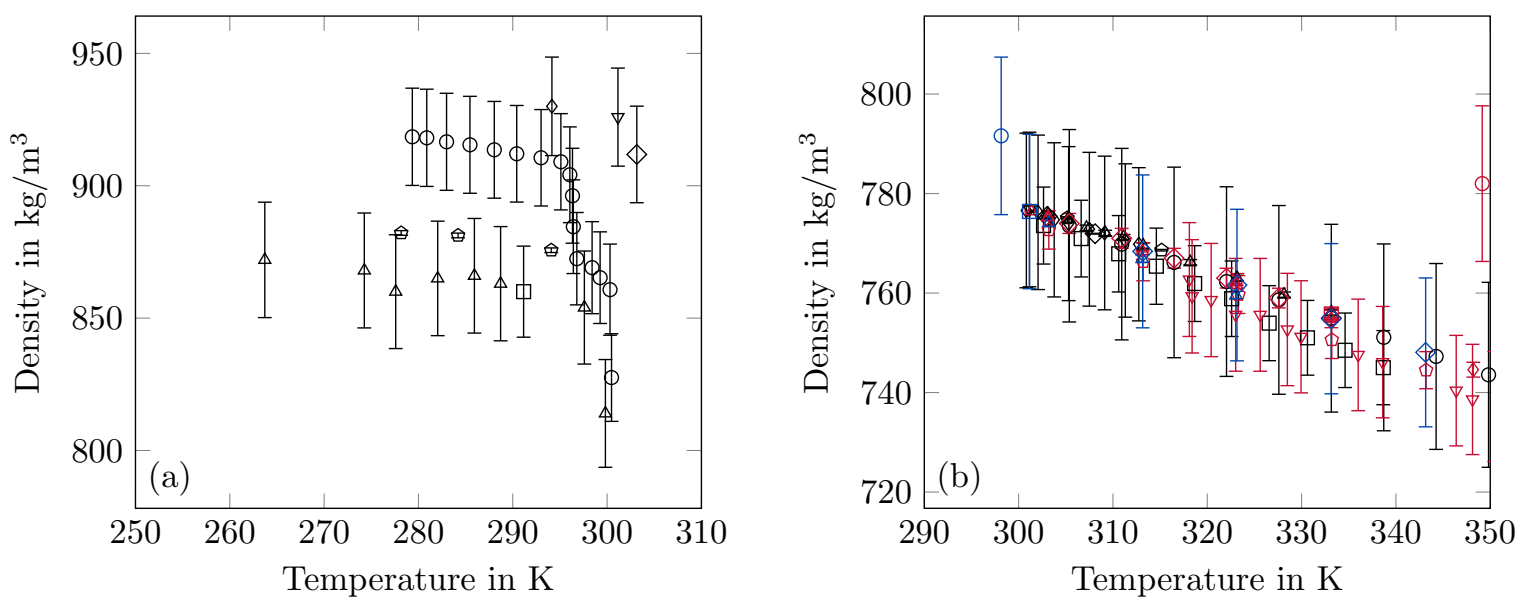

Figure 2. Summary of density data from the literature in the solid (a) and liquid (b) state. The error bars are the specified uncertainty of the data. The values named OR are results from our own research. (a) $\circ[$ [62] $\square[$ 64] $\diamond[66] \Delta$ [67] $\nabla$ [73] $\diamond[74] \diamond$ OR; (b) $\circ[6] \square[27] \diamond[27] \Delta$ [28] $\nabla$ [61] $\diamond[62] \diamond[63] \circ[64]$ $\square[65] \diamond[67] \Delta[68] \nabla[69] \diamond[70] \diamond[71] \circ[72] \square[73] \diamond[75] \Delta$ OR. 


\subsection{Heat Capacity}

The heat capacities are most commonly measured by means of DSC which can be operated with different methods. The dynamic mode works with a constant heating rate and has been applied by Höhne [76], Djordjevic and Laub [46], Durupt et al. [77], Fonseca et al. [47] and Vélez et al. [27]. The step mode applies discrete temperature steps to the sample and the heat flow is determined for each temperature step [45]. Dynamic measurements have been conducted in the framework of our own research and the results are included as well. Some researchers have measured the specific heat capacity with AC $[53,54,78]$ and there is no information about the measuring principle for the data of Shlosinger and Bentilla [67]. A summary of all available data on the heat capacity can be found in Table 3 and Figure 3.

Table 3. Summary of heat capacity data from the literature. The number behind the abbreviation DSC describes either the heating rate $(\mathrm{K} / \mathrm{min})$ or the step size $(\mathrm{K})$ of the applied measurement method.

\begin{tabular}{lcccccc}
\hline Reference & $\begin{array}{c}\text { Purity } \\
\text { in } \%\end{array}$ & Year & Method & $\begin{array}{c}\text { Uncertainty } \\
\text { in \% }\end{array}$ & $\begin{array}{c}\text { Observations } \\
\text { Solid }\end{array}$ & Liquid \\
\hline Vélez et al. [27] & 99 & 2015 & DSC, 5 K/min & $2^{a}$ & 166 & 198 \\
Huang et al. [45] & 99 & 2005 & DSC, 1 K & 1 & 0 & 25 \\
Djordjevic and Laub [46] & n/a & 1983 & DSC, 5 K/min & $3^{a}$ & 1 & 1 \\
Fonseca et al. [47] & 99.5 & 2014 & DSC, $0.48 \mathrm{~K} / \mathrm{min}$ & 1 & 5 & 0 \\
Parks et al. [53] & 96 & 1949 & $\mathrm{AC}$ & 0.7 & 21 & 1 \\
Messerly et al. [54] & $99.98(\mathrm{~mol})$ & 1967 & $\mathrm{AC}$ & 0.2 & 77 & 11 \\
Shlosinger and Bentilla [67] & n/a & 1965 & $\mathrm{NC}$ & $5^{b}$ & 0 & 5 \\
Höhne [76] & very pure & 1981 & DSC, 10 K/min & 5 & 0 & 3 \\
Durupt et al. [77] & 99 & 1996 & DSC & $3^{a}$ & 0 & 9 \\
van Miltenburg [78] & 99.8 & 1999 & AC & 0.2 & 0 & 38 \\
Own research (OR) & 97 & 2018 & DSC, 1 K/min & 3 & 41 & 57 \\
\hline
\end{tabular}

${ }^{a}$ Taken from Czichos et al. [79], ${ }^{b}$ Assumption.
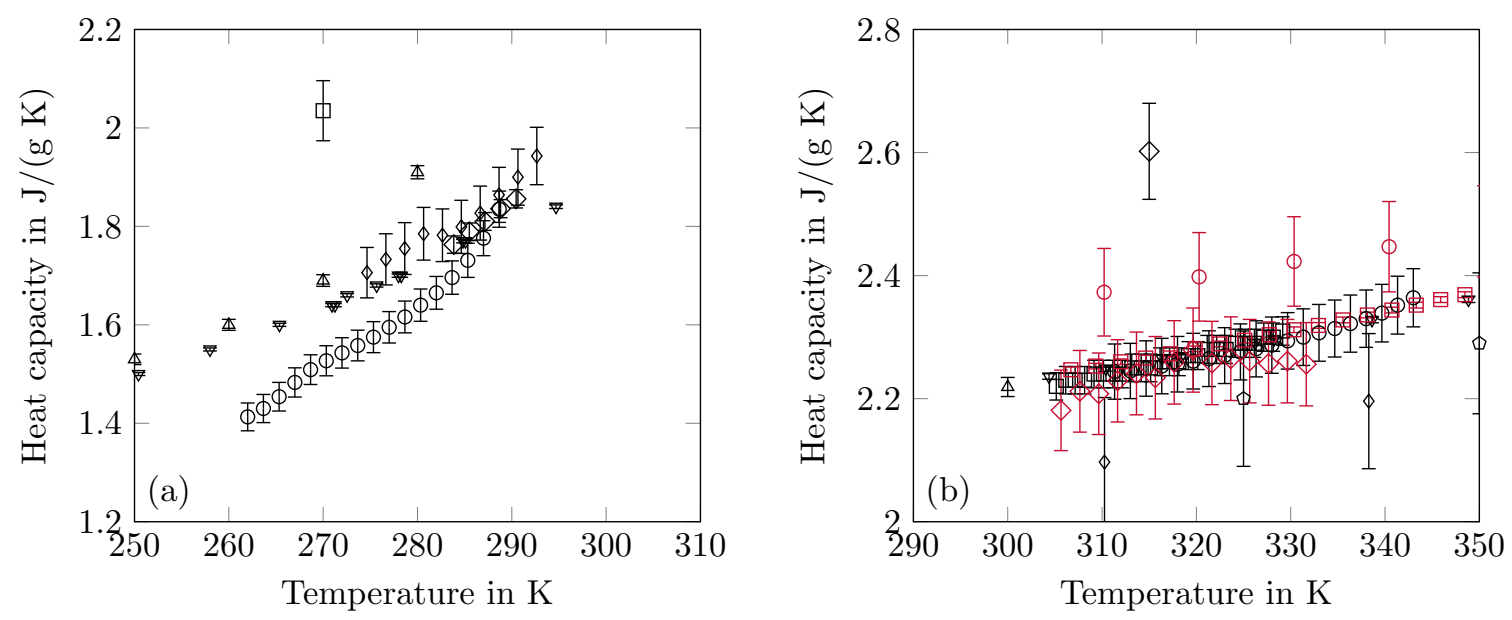

Figure 3. Summary of heat capacity data from the literature in the solid (a) and liquid (b) state. The error bars are the specified uncertainty of the data. The displayed data of Vélez et al. [27] and of our own research (OR) are reduced to every tenth and fourth point of the available results, respectively. (a) $\circ$ [27] $\square$ [46] $\diamond[47] \Delta$ [53] $\nabla$ [54] $\diamond$ OR; (b) $\circ$ [27] $\square$ [45] $\diamond[46] \Delta$ [53] $\nabla$ [54] $\diamond[67] \diamond[76] \circ$ [77] $\square[78] \diamond \mathrm{OR}$.

\subsection{Thermal Conductivity}

Thermal conductivities have been measured with transient as well as stationary measurement methods. Irby et al. [80], Harish et al. [81], Wu et al. [82], Vélez et al. [27], Khadiran et al. [83] and Águila V et al. [84] applied the transient hot wire (TW) method and Jeon et al. [32], Yu et al. [38], Motahar et al. [85] and Motahar et al. [86] used a transient plane source (TP) to measure solid and liquid 
state thermal conductivities while Ho and Gao [28] have measured the liquid state only with a transient thermal analyser (TA). The stationary methods can be categorized in measurement set-ups analysing the heat flow between parallel plates (SP, stationary plate) $[87,88]$ or coaxial cylinder systems (SC, stationary cylinder) [89-91]. Irby et al. [80] have achieved some additional results by applying inverse methods (IM) like phase change- and transient conduction experiments. Thermal conductivity measurements which can not be classified according to the above mentioned categories have been performed by Mustafaev [92], Rastorguev and Bogatov [93] and Holmen et al. [94]. A summary of all available data on the thermal conductivity can be found in Table 4 and Figure 4.

Table 4. Summary of thermal conductivity data from the literature.

\begin{tabular}{|c|c|c|c|c|c|c|}
\hline \multirow[t]{2}{*}{ Reference } & \multirow{2}{*}{$\begin{array}{l}\text { Purity } \\
\text { in } \%\end{array}$} & \multirow[t]{2}{*}{ Year } & \multirow[t]{2}{*}{ Method } & \multirow{2}{*}{$\begin{array}{c}\text { Uncertainty } \\
\text { in } \%\end{array}$} & \multicolumn{2}{|c|}{ Observations } \\
\hline & & & & & Solid & Liquid \\
\hline Vélez et al. [27] & 99 & 2015 & TW & 2 & 20 & 10 \\
\hline Ho and Gao [28] & 99.9 & 2009 & $\mathrm{TA}$ & 5 & 0 & 7 \\
\hline Jeon et al. [32] ${ }^{a}$ & $\mathrm{n} / \mathrm{a}$ & 2012 & $\mathrm{TP}$ & $5^{b}$ & 1 & 0 \\
\hline Yu et al. [38] ${ }^{a}$ & 98.5 & 2014 & $\mathrm{TP}$ & $5^{c}$ & 1 & 0 \\
\hline Zhang et al. [39] ${ }^{a}$ & 90 & 2012 & $\mathrm{TP}$ & $5^{d}$ & 1 & 0 \\
\hline Irby et al. [80] & $\mathrm{n} / \mathrm{a}$ & 1988 & TW/IM & $1.5-3$ & $15 / 3$ & 13 \\
\hline Harish et al. [81] ${ }^{e}$ & $\mathrm{n} / \mathrm{a}$ & 2015 & TW & 3 & 2 & 7 \\
\hline Wu et al. [82] & 99 & 2015 & TW & 2 & 3 & 3 \\
\hline Khadiran et al. [83] & $\mathrm{n} / \mathrm{a}$ & 2015 & TW & $5^{f}$ & 1 & 1 \\
\hline Águila V et al. [84] & 99 & 2018 & TW & 5 & 0 & 4 \\
\hline Motahar et al. [85] & 99 & 2014 & $\mathrm{TP}$ & 1 & 5 & 6 \\
\hline Motahar et al. [86] & 99 & 2016 & $\mathrm{TP}$ & 2 & 5 & 6 \\
\hline Sakiadis and Coates [87] & 95 & 1957 & SP & 1 & 0 & 17 \\
\hline Powell et al. [88] & $\mathrm{n} / \mathrm{a}$ & 1961 & SP & $2^{g}$ & 6 & 6 \\
\hline Ziebland and Patient [89] & $\mathrm{n} / \mathrm{a}$ & 1962 & SC & 2 & 0 & 8 \\
\hline Griggs and Yarbrough [90] & 99 & 1978 & SC & 30 & 4 & 0 \\
\hline Yarbrough and Kuan [91] & $\mathrm{n} / \mathrm{a}$ & 1981 & SC & $10-14$ & 5 & 0 \\
\hline Mustafaev [92] & $\mathrm{n} / \mathrm{a}$ & 1973 & NC & 2 & 0 & 4 \\
\hline Rastorguev and Bogatov [93] & $\mathrm{n} / \mathrm{a}$ & 1972 & NC & $1.3^{h}$ & 0 & 4 \\
\hline Holmen et al. [94] & 99 & 2002 & NC & 20 & 1 & 1 \\
\hline
\end{tabular}

${ }^{a}$ No information about temperature given; $298.15 \mathrm{~K}$ assumed; ${ }^{b}$ From manufacturers data sheet [95]; ${ }^{c}$ From manufacturers data sheet [96]; ${ }^{d}$ Assumption; ${ }^{e}$ Octadecane has been applied for calibration purpose; ${ }^{f}$ Taken from Águila V et al. [84]; ${ }^{g}$ Taken from Czichos et al. [79]; ${ }^{h}$ Taken from Rastorguev et al. [97];
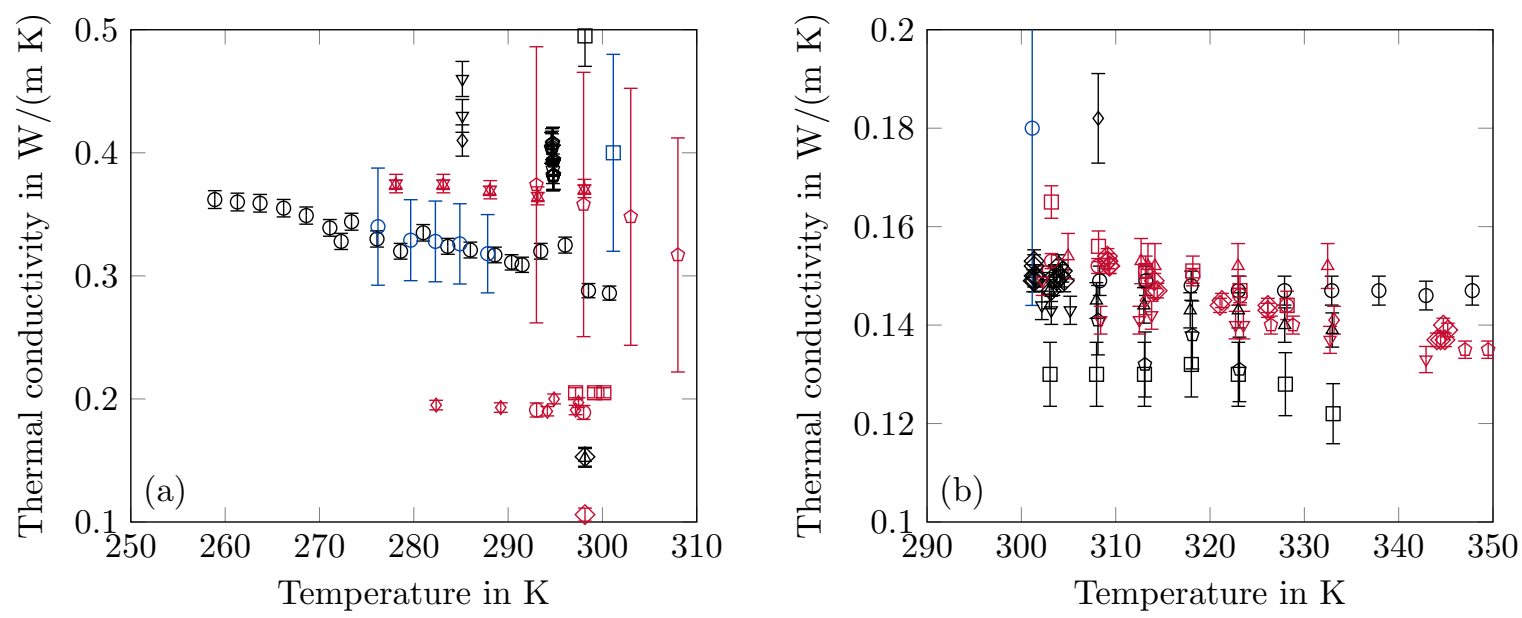

Figure 4. Summary of thermal conductivity data from the literature in the solid (a) and liquid (b) state. The error bars are the specified uncertainty of the data. (a) $\circ[27] \square[32] \diamond[38] \Delta[39] \nabla[$ [80] $\diamond[80]$ $\diamond[80] \circ[81] \square[82] \diamond[83] \Delta[85] \nabla[$ [86] $\diamond[88] \diamond[90] \circ[91] \square[$ [94]; (b) $\circ$ [27] $\square[28] \diamond[80] \Delta[81] \nabla[82]$ $\diamond[83] \diamond[84] \circ[85] \square[86] \diamond[87] \Delta[88] \nabla[89] \diamond[92] \diamond[93] \circ[94]$. 


\subsection{Viscosity}

The majority of researchers have determined the viscosity of octadecane with rotational rheometers (RR) [28,84,85,98]. Results of our own measurements with a translational rheometer (TR), the so called IMETER, are included in the publication of Delgado et al. [98]. Hogenboom et al. [99] and Ducoulombier et al. [100] have applied falling-body viscometers (FV) and Dover and Hensley [63] used an Ostwald capillary viscometer (CV). A self-built vibrating-wire viscometer (VV) has been designed for the measurements of Caudwell et al. [70] and there is no information about the measuring principle for the data of Rossini [6]. A summary of all available data on the viscosity can be found in Table 5 and Figure 5.

Table 5. Summary of viscosity data from the literature.

\begin{tabular}{|c|c|c|c|c|c|}
\hline Reference & $\begin{array}{l}\text { Purity } \\
\text { in } \%\end{array}$ & Year & Method & $\begin{array}{c}\text { Uncertainty } \\
\text { in } \%\end{array}$ & $\begin{array}{c}\text { Observations } \\
\text { Liquid }\end{array}$ \\
\hline Rossini [6] & $\mathrm{n} / \mathrm{a}$ & 1952 & $\mathrm{NC}$ & 0.7 & 58 \\
\hline Ho and Gao [28] & 99.9 & 2009 & $\mathrm{RR}$ & 1 & 11 \\
\hline Dover and Hensley [63] & $\mathrm{n} / \mathrm{a}$ & 1934 & $\mathrm{CV}$ & $1^{a}$ & 2 \\
\hline Caudwell et al. [70] & 99 & 2004 & VV & 2 & 7 \\
\hline Águila V et al. [84] & 99 & 2018 & RR & 1 & 6 \\
\hline Motahar et al. [85] & 99 & 2014 & $\mathrm{RR}$ & 4 & 6 \\
\hline Delgado et al. [98] ${ }^{b}$ & 97 & 2018 & $\mathrm{TR} / \mathrm{RR} / \mathrm{RR}$ & $1.38 / 7.74 / 2.27$ & $103 / 110^{c} / 148^{c}$ \\
\hline Hogenboom et al. [99] & high purity & 1967 & $\mathrm{FV}$ & 5 & 3 \\
\hline Ducoulombier et al. [100] & purum & 1986 & FV & $1^{d}$ & 4 \\
\hline
\end{tabular}

${ }^{a}$ Assumption; ${ }^{b}$ The listed data are for the IMETER/Anton Paar MCR502/TA Instruments AR G2. ${ }^{c}$ The data points are acquired for two different operating modes (rotational and oscillatory).

${ }^{d}$ Uncertainty of the falling time of the falling body only.

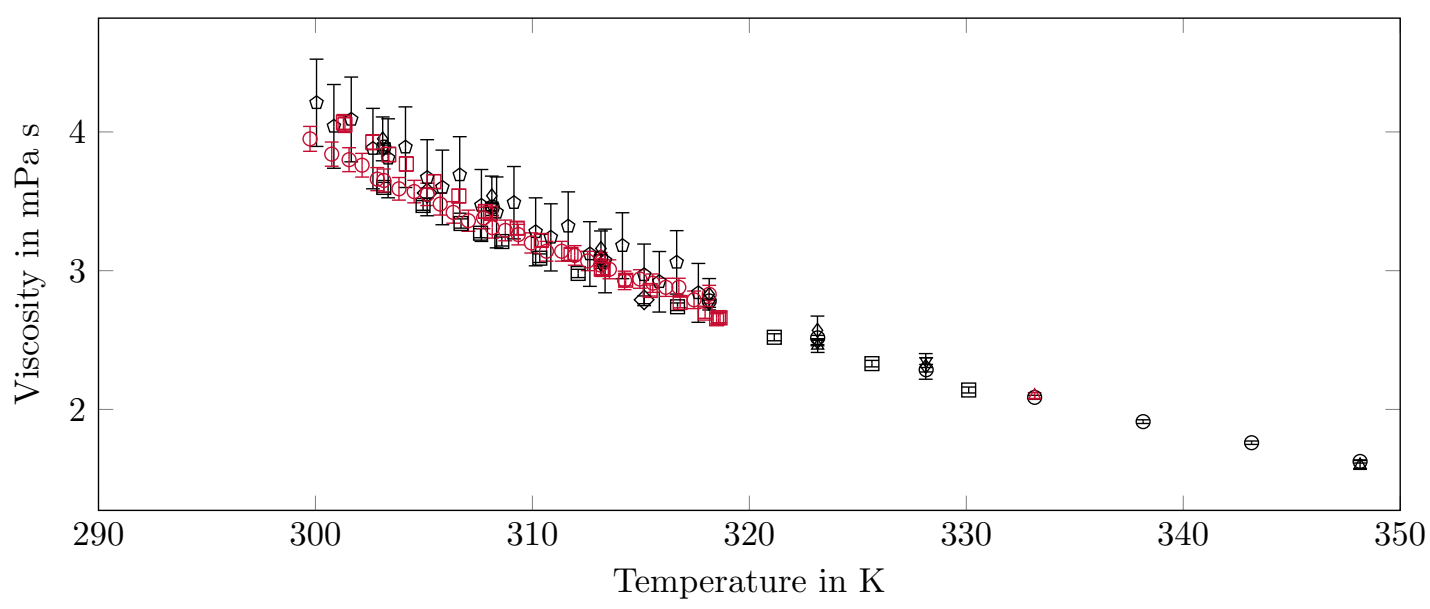

Figure 5. Summary of viscosity data from the literature. The error bars are the specified uncertainty of the data. The displayed data of Delgado et al. [98] are reduced to every fifth point of the available results. $\circ[6] \square[28] \diamond[63] \Delta[70] \nabla[$ [84] $\diamond[85] \diamond[98] \circ[98] \square[98] \diamond[99] \Delta[100]$.

\section{Preselection of Data}

The results presented in Section 5 are obtained after a preselection of the literature values by excluding obvious outliers and less appropriate data. The reasons for the exclusion are the following:

\subsection{Melting Temperature and Enthalpy}

- Only temperature data which were achieved as the extrapolated onset temperature $T_{e}$ or the temperature $T_{*}$ (see Section 2.1) are considered since these temperatures seem to represent a realistic melting point of octadecane. 
- Jeong et al. [23] and Qiu et al. [31] were removed because they were outliers on the high and low side of temperature data in the literature.

- Boudouh et al. [48], Babich et al. [40] and Zhang et al. [24] were removed because they were outliers on the high and low side of literature melting enthalpy data.

- The data of He et al. [37], Zhang et al. [39] and Zhu et al. [41] were excluded since these authors investigated octadecane of low purity.

- Yu et al. [38] were not considered due to identical melting point and enthalpy results compared to a previous publication of the same co-authors [37] despite supposedly different purity grades of octadecane.

\subsection{Density}

- One datapoint of Shlosinger and Bentilla [67] was neglected since it was located in the 2-phase-region.

- The whole series of solid state data from Seyer et al. [62] was removed because of the indicated solid-solid transformation.

- All data of Würflinger and Schneider [73] were excluded due to the applied inverse method for determining the solid-state density.

- The data of Müller and Lonsdale [74] were neglected since their results where achieved with X-ray measurements resulting in very high theoretical density calculations based on the distance between the molecules.

- Liquid state densities from van Hook and Silver [64] were excluded because of incomprehensible corrections in their data.

- The liquid state data point of McKinney [72] was removed since it was given at a temperature of $25{ }^{\circ} \mathrm{C}$ which is obviously in the solid state.

\subsection{Thermal Conductivity}

- The thermal conductivity data of Harish et al. [81] were not considered because they applied octadecane itself for calibrating their measuring system.

- Solid state data points of Jeon et al. [32] and Khadiran et al. [83] were removed because they are outliers on the high and low side of data in the literature.

- Yu et al. [38] and Zhang et al. [39] were excluded because of the ambiguous specifications of the evaluation temperature (at room temperature...).

- Two data point of Griggs and Yarbrough [90] were removed from the solid state data due to evaluation temperatures above the melting point.

- Liquid state data of Holmen et al. [94] and Khadiran et al. [83] were neglected since they were significantly higher than the remaining data points.

\subsection{Heat Capacity}

- Data points near the phase change temperature were neglected since they may be affected by phase change phenomena and therefore do not describe pure sensible heating of octadecane.

- The liquid state heat capacity of Parks et al. [53] was excluded because the indicated temperature is in the solid state range.

- The data of Djordjevic and Laub [46] were removed in both phases because they were outliers on the high side of values found in the literature.

\subsection{Viscosity}

The viscosity data of Hogenboom et al. [99] were not considered because they were measured at higher temperatures out of the range of interest for our study. 


\section{Statistics}

For all properties, we investigated the relationship with temperature and chose the specification with the highest polynomial of temperature that was found to be statistically significant, i.e., for the corresponding parameter of which we could reject the null hypothesis $H_{0}: \beta_{k}=0$ in a two-sided test, where $\beta_{k}$ denotes the parameters. Except for the viscosity, where we followed the recommendation of the VDI heat atlas [101]:

$$
\ln (\eta)=A+\frac{B}{T}
$$

All of these relationships are linear in parameters and hence we fitted specifications of the following form:

$$
y_{i}=\mathbf{x}_{i}^{\prime} \boldsymbol{\beta}+\varepsilon_{i},
$$

were $^{\prime}$ is the transpose of a vector and therefore $\mathbf{x}_{i}^{\prime} \boldsymbol{\beta}$ is the scalar product. The index $i$ denotes the observation, $y_{i}$ in turn represents the measured values of (solid and liquid) density, (solid and liquid) heat capacity, (solid and liquid) thermal conductivity, and the natural logarithm of viscosity. The vector $\beta$ denotes the corresponding true (unobserved) parameter vector and $\varepsilon$ is a random error term that is potentially correlated for different observations from the same study. In the most common case, we ended up fitting a linear relationship and $\mathbf{x}_{i}$ hence comprises a constant and the temperature $T_{i}$ at which the measurement was obtained (i.e., $\mathbf{x}_{i}=\left[\begin{array}{ll}1 & T_{i}\end{array}\right]^{\prime}$ ). Specifically, we fitted this simple linear model for the liquid density and the solid and liquid thermal conductivity. In the solid density and the solid thermal conductivity case, we found no significant evidence for a relationship with temperature and therefore only fitted a constant (i.e., $x_{i}=1$ ). For liquid heat capacity, we found a significant quadratic relationship with temperature and hence fitted a second-order polynomial (i.e., $\left.\mathbf{x}_{i}=\left[\begin{array}{lll}1 & T_{i} & \left(T_{i}\right)^{2}\end{array}\right]^{\prime}\right)$. Finally, for the viscosity, we fitted a constant and a linear relationship with the inverse temperature (i.e., $\mathbf{x}_{i}=\left[\begin{array}{ll}1 & \left(T_{i}\right)^{-1}\end{array}\right]^{\prime}$ ).

Besides the data points $\left(y_{i}, T_{i}\right)$ themselves, we have information on the corresponding uncertainty in the measurement of $y$. If this reported uncertainty actually represents a good approximation to the relative size of the unsystematic component $\varepsilon_{i}$ in (2) across observations, it can be used to weight observations in the estimation in order to obtain more precise estimates of $\beta$. For the solid density and solid heat conductivity, we expect the measurement error to be of minor magnitude compared to variation around the systematic relationship that is introduced e.g., by differences in the physical sample preparation. Further, for viscosity, the uncertainty refers to the level while we fit a linear model to the natural logarithm. In these three cases, we therefore decided not to use the provided uncertainty information in the corresponding regressions and used the ordinary least squares (OLS) estimator:

$$
\widehat{\boldsymbol{\beta}}_{O L S}=\left(\mathbf{X}^{\prime} \mathbf{X}\right)^{-1} \mathbf{X}^{\prime} \mathbf{y},
$$

where $\mathbf{X}=\left[\begin{array}{llll}\mathbf{x}_{1} & \mathbf{x}_{2} & \ldots & \mathbf{x}_{N}\end{array}\right]^{\prime}, \mathbf{y}=\left[\begin{array}{llll}y_{1} & y_{2} & \ldots & y_{N}\end{array}\right]^{\prime}$, and $N$ denotes the number of observations. Note that-as mentioned above-we did not find a significant effect of temperature for two of these cases and therefore finally only fitted a constant, in which case (3) reduces to taking the mean of $y$.

For all other properties, we expect the provided uncertainties to capture the magnitude of the unsystematic variation associated with different observations of the same property well and therefore estimated the corresponding parameter vectors $\beta$ with a weighted least squares (WLS) procedure. Specifically, denoting the uncertainty of an observation by $\sigma$, the estimates are obtained using the following estimator:

$$
\widehat{\boldsymbol{\beta}}_{W L S}=\left(\mathbf{X}^{\prime} \mathbf{W} \mathbf{X}\right)^{-1} \mathbf{X}^{\prime} \mathbf{W} \mathbf{y},
$$

where $\mathbf{W}$ is an $N \times N$ diagonal weighting matrix with $w_{i i}=1 / \sigma^{2}$.

With an estimated parameter vector $\widehat{\boldsymbol{\beta}}$ at hand, we can calculate fitted values: 


$$
\widehat{y}=\mathbf{x}^{\prime} \widehat{\boldsymbol{\beta}},
$$

where $\mathbf{x}$ can be an actual data point or any point at which we are interested in the predicted physical property. Fitted values are depicted by the solid lines in Figure 6 in Section 5.

In assessing the precision with which we estimated $\widehat{\boldsymbol{\beta}}$ (and hence $\widehat{y}$ ), we allow errors of different observations from the same study to be correlated by relying on cluster-robust inference. Specifically, denoting the different studies/clusters by $g=1,2, \ldots, G$, the estimated variance-covariance matrix of the estimated parameter vectors $\widehat{\boldsymbol{\beta}}_{O L S}$ and $\widehat{\boldsymbol{\beta}}_{W L S}$ are given by:

$$
\widehat{\mathbf{V}}_{O L S}=\left(\mathbf{X}^{\prime} \mathbf{X}\right)^{-1}\left(\sum_{g=1}^{G} \mathbf{X}_{g}^{\prime} \tilde{\varepsilon}_{g} \tilde{\varepsilon}_{g}^{\prime} \mathbf{X}_{g}\right)\left(\mathbf{X}^{\prime} \mathbf{X}\right)^{-1}
$$

and

$$
\widehat{\mathbf{V}}_{W L S}=\left(\mathbf{X}^{\prime} \mathbf{W} \mathbf{X}\right)^{-1}\left(\sum_{g=1}^{G} \mathbf{X}_{g}^{\prime} \mathbf{W}_{g} \tilde{\varepsilon}_{g} \tilde{\varepsilon}_{g}^{\prime} \mathbf{W}_{g} \mathbf{X}_{g}\right)\left(\mathbf{X}^{\prime} \mathbf{W} \mathbf{X}\right)^{-1},
$$

where $\tilde{\varepsilon}_{g}=\sqrt{\frac{G}{G-1} \frac{N-1}{N-K}}\left(\mathbf{y}_{g}-\mathbf{X}_{g}^{\prime} \widehat{\boldsymbol{\beta}}\right)$ is the vector of residuals (multiplied with a correction factor for small numbers of clusters) and the $g$ subscript indicates that only the elements of the corresponding matrices or vectors that belong to cluster $g$ are considered (see Cameron and Miller [102] for details on cluster-robust standard errors).

Given the fitted values and an estimate of the variance-covariance matrix, we can construct $(1-\alpha) \times 100 \%$ confidence intervals for all estimated relationships as follows:

$$
\widehat{y} \pm t_{\alpha / 2} \sqrt{\mathbf{x}^{\prime} \widehat{\mathbf{V}} \mathbf{x}}
$$

where $t_{\alpha / 2}$ is the critical value from a t-distribution with $G-1$ degrees of freedom for a significance level $\alpha$ (i.e., $\left.P\left(t<-t_{\alpha / 2}\right)+P\left(t>t_{\alpha / 2}\right)=1-\alpha\right)$. The $95 \%$ and $99 \%$ confidence intervals are depicted in Figure 6 as dashed and dotted lines, respectively. For the viscosity, we display the exponential of both the fitted values and the confidence bounds.

All statistical analyses were performed using Stata (version 15.1 MP).

\section{Results and Discussion}

Our statistical analysis reveals a clear difference between the confidence that we can put into the fit functions that describe the solid and liquid material properties of octadecane (Figure 6). All fit functions for the liquid state are determined with small confidence intervals. In contrast, two of the three solid state fit functions are highly uncertain, namely the ones describing the solid thermal conductivity and the solid density. In the first case, there are enough data points but their distribution is broad and without a recognizable trend. Also remarkable is the accumulation of points around a low value of $0.2 \mathrm{~W} /(\mathrm{m} \mathrm{K})$, which were measured by different authors. Therefore, the confidence interval surrounding the mean is wide and no temperature dependence of the solid thermal conductivity could be determined with statistical significance. In the second case, the statistical analysis is constrained by the small number of available data points respectively the small number of studies which measured the solid density. Here, too no temperature dependency could be determined with statistical significance. Moreover, the $95 \%$ confidence interval is wider than the range of the data points. We assume that the reasons for the scattered solid values is sample preparation (degassing and cooling rate) and experimental procedure, which is especially important for solids [103].

Furthermore, a few values for the viscosity and the liquid density lie in the solid phase, which is defined by our mean melt temperature. The reasons for this are uncertainties in the temperature measurements. 


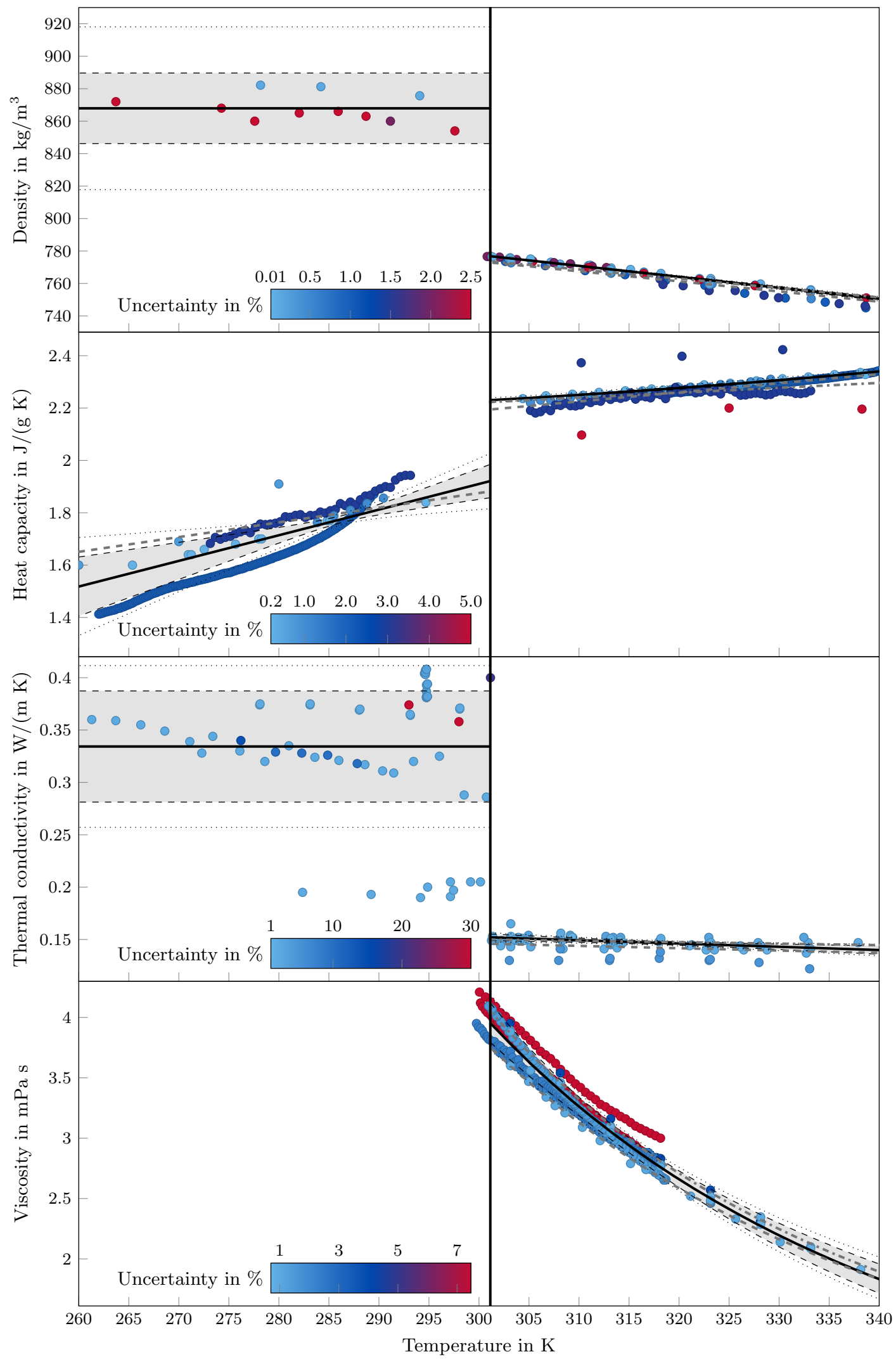

Figure 6. Summary of the estimated fit functions for the temperature-dependent thermophysical properties of octadecane. The displayed points indicate the preselected data applied for the calculation and the color scale corresponds to the associated uncertainty. The grey shaded areas between the dashed lines describe the confidence interval of $95 \%$ and the dotted lines a confidence of $99 \%$. 
Table 6 summarizes the estimated parameters of the fit functions for the solid and the liquid state. The fit functions are valid from the mean melting point to $\pm 40 \mathrm{~K}$. Also included in the table are the mean melting point $(301.13 \mathrm{~K})$ and the mean melting enthalpy $(236.98 \mathrm{~J} / \mathrm{g})$. The functions for the indicated confidence intervals are summarized in the Appendix (Equations (A1)-(A18)).

Table 6. Estimated fit functions for the temperature-dependent thermophysical properties of octadecane and its mean melting temperature and enthalpy.

\begin{tabular}{|c|c|c|c|}
\hline Property & $\begin{array}{c}\text { Solid State } \\
(261.13 \mathrm{~K}-301.13 \mathrm{~K})\end{array}$ & & $\begin{array}{c}\text { Liquid State } \\
(301.13 \mathrm{~K}-341.13 \mathrm{~K})\end{array}$ \\
\hline Density in $\mathrm{kg} / \mathrm{m}^{3}$ & 867.914 & & $979.826-0.674 \cdot T$ \\
\hline Heat capacity in J/(g K) & $-1.029+9.797 \cdot 10^{-3} \cdot T$ & & $3.247-8.861 \cdot 10^{-3} \cdot T+1.821 \cdot 10^{-5} \cdot T^{2}$ \\
\hline Thermal conductivity in $\mathrm{W} /(\mathrm{m} \mathrm{K})$ & 0.334 & & $0.246-3.121 \cdot 10^{-4} \cdot T$ \\
\hline Viscosity in $\mathrm{mPa} s$ & - & & $\exp (-5.353+2026.013 / T)$ \\
\hline Melting temperature in $\mathrm{K}$ & - & 301.13 & - \\
\hline Melting enthalpy in J/g & - & 236.98 & - \\
\hline
\end{tabular}

A comparison with existing functions for the liquid state properties of octadecane from the VDI heat atlas [101] and from Yaws [104] shows satisfactory agreement with the determined fit functions in the temperature interval under consideration. The maximum relative deviations between estimated fit functions and the functions are $0.5 \%, 1.9 \%, 4 \%$ and $5 \%$ for the liquid state density, heat capacity, thermal conductivity and viscosity, respectively. For the solid state properties there is only one function available from Yaws [104] for the heat capacity which shows a maximum relative deviation of $9 \%$. A graphical overview of the functions can be found in Figure A1 in Appendix A.2.

\section{Conclusions}

The temperature-dependent functions of the thermophysical properties of octadecane derived in this review paper can be used for numerical and/or analytical calculations. The usage of these functions improves the comparability of studies and simplifies validation. The given confidence intervals help to estimate the accuracy of the results. Generally, the confidence intervals around the liquid functions are considerably thinner than around the solid functions. The two properties which are most insecure are the solid thermal conductivity and the solid density. In our opinion, these two quantities are both greatly affected by sample preparation in the experiments. We therefore hope that this research leads to further measurements with a standardized measurement protocol.

Author Contributions: Conceptualization, M.F. and S.H. and A.K.-H.; methodology, M.F., S.H. and J.W.; formal analysis, J.W.; investigation, M.F. and S.H.; data curation, M.F. and S.H.; writing-original draft preparation, M.F., S.H. and J.W.; writing-review and editing, M.F., S.H., J.W., A.K.-H. and D.B.; visualization, S.H. and M.F.; supervision, D.B.; project administration, M.F., A.K.-H. and D.B.; funding acquisition, A.K.-H. and D.B.

Funding: The authors are grateful for the financial support of the German Research Foundation (DFG) under grant no. BR 1713/20-1.

Acknowledgments: This publication was funded by the German Research Foundation (DFG) and the University of Bayreuth in the funding programme Open Access Publishing.

Conflicts of Interest: The authors declare no conflict of interest.

\section{Abbreviations}

The following abbreviations are used in this manuscript:

A Coefficient

B Coefficient

AC Adiabatic calorimeter

CV Capillary viscometer

DM Dilatometer

DSC Differential scanning calorimetry 
FV Falling-body viscometer

$g \quad$ Study/cluster number

G Total number of studies/clusters

HM Hydrometer

HW Hydrostatic weighing

$H_{0} \quad$ Null hypothesis

IM Inverse method

$N \quad$ Number of observations

$\mathrm{n} / \mathrm{a} \quad$ Not available

NC Not classified

OR Own research

PM Pycnometer

RR Rotational rheometer

SC Stationary cylinder

SP Stationary plate

$t_{\alpha / 2} \quad$ Critical value from a student $\mathrm{t}$-distribution

$T \quad$ Temperature

TA Transient thermal analyser

$T_{C} \quad$ Extrapolated offset temperature

$T_{e} \quad$ Extrapolated onset temperature

$T_{f} \quad$ Final peak temperature

$T_{i} \quad$ Initial peak temperature

$T_{p} \quad$ Peak maximum temperature

TP Transient plane source

$T_{*} \quad$ Temperature with insufficient information about its determination

TR Translational rheometer

TW Transient hot wire

VE Vibrating-element

VV Vibrating viscometer

$\widehat{\mathbf{V}}_{\text {OLS }}$ Esitmated variance-covariance matrix of the ordinary least squares estimator

$\widehat{\mathbf{V}}_{\text {WLS }}$ Esitmated variance-covariance matrix of the weighted least squares estimator

W Weighting matrix

$\mathbf{x} \quad$ Explanantory variable vector

X Explanantory variable matrix

y Measured values

y Vector of measured values

$\widehat{y} \quad$ Estimated value

$\alpha \quad$ Significance level

$\beta \quad$ Parameter

$\beta \quad$ Parameter vector

$\widehat{\beta} \quad$ Estimated parameter vector

$\widehat{\boldsymbol{\beta}}_{\text {OLS }} \quad$ Ordinary least squares estimator

$\widehat{\boldsymbol{\beta}}_{W L S} \quad$ Weighted least squares estimator

$\varepsilon \quad$ Random error term

$\tilde{\varepsilon} \quad$ Vector of residuals

$\eta \quad$ Viscosity

$\sigma \quad$ Uncertainty of observation 


\section{Appendix A}

Appendix A.1. Estimated Fit Functions and Confidence Intervals

Appendix A.1.1. Melting Temperature

Functions for the confidence interval of $95 \%$ :

$$
\max / \min =301.1327586 \pm 0.164303685
$$

Functions for the confidence interval of $99 \%$ :

$$
\max / \min =301.1327586 \pm 0.221642561
$$

Appendix A.1.2. Melting Enthalpy

Functions for the confidence interval of 95\%:

$$
\max / \min =236.9828571 \pm 2.901537323
$$

Functions for the confidence interval of $99 \%$ :

$$
\max / \min =236.9828571 \pm 3.957815931
$$

Appendix A.1.3. Density

Functions for the confidence interval of $95 \%$, solid state:

$$
\max / \min =867.9136364 \pm 21.74247525
$$

Functions for the confidence interval of $99 \%$, solid state:

$$
\max / \min =867.9136364 \pm 50.15293385
$$

Functions for the confidence interval of 95\%, liquid state:

$$
\begin{array}{r}
\max / \min =979.8260505-0.674202476 \cdot T \pm 2.131449546 \cdot(9.778011011+ \\
\left.-0.065513473 \cdot T+0.000109976 \cdot T^{2}\right)^{1 / 2}
\end{array}
$$

Functions for the confidence interval of $99 \%$, liquid state:

$$
\begin{array}{r}
\max / \min =979.8260505-0.674202476 \cdot T \pm 2.946712883 \cdot(9.778011011+ \\
\left.-0.065513473 \cdot T+0.000109976 \cdot T^{2}\right)^{1 / 2}
\end{array}
$$

\section{Appendix A.1.4. Heat Capacity}

Functions for the confidence interval of $95 \%$, solid state:

$$
\begin{array}{r}
\max / \min =-1.029094213+0.009797222 \cdot T \pm 2.776445105 \cdot(0.191470758+ \\
\left.-0.001336832 \cdot T+2.33367 \cdot 10^{-6} \cdot T^{2}\right)^{1 / 2}
\end{array}
$$

Functions for the confidence interval of $99 \%$, solid state:

$$
\begin{array}{r}
\max / \min =-1.029094213+0.009797222 \cdot T \pm 4.604094871 \cdot(0.191470758+ \\
\left.-0.001336832 \cdot T+2.33367 \cdot 10^{-6} \cdot T^{2}\right)^{1 / 2}
\end{array}
$$

Functions for the confidence interval of $95 \%$, liquid state:

$$
\begin{aligned}
\max / \min & =3.246741729-0.008860513 \cdot T+1.82147 \cdot 10^{-5} \cdot T^{2} \pm 2.364624252 \cdot(0.407699103+ \\
& \left.-0.005073903 \cdot T+2.36524 \cdot 10^{-5} \cdot T^{2}-4.89464 \cdot 10^{-8} \cdot T^{3}+3.79394 \cdot 10^{-11} \cdot T^{4}\right)^{1 / 2}
\end{aligned}
$$


Functions for the confidence interval of $99 \%$, liquid state:

$$
\begin{aligned}
\max / \min & =3.246741729-0.008860513 \cdot T+1.82147 \cdot 10^{-5} \cdot T^{2} \pm 3.499483297 \cdot(0.407699103+ \\
& \left.-0.005073903 \cdot T+2.36524 \cdot 10^{-5} \cdot T^{2}-4.89464 \cdot 10^{-8} \cdot T^{3}+3.79394 \cdot 10^{-11} \cdot T^{4}\right)^{1 / 2}
\end{aligned}
$$

Appendix A.1.5. Thermal Conductivity

Functions for the confidence interval of $95 \%$, solid state:

$$
\max / \min =0.334295082 \pm 0.053078735
$$

Functions for the confidence interval of $99 \%$, solid state:

$$
\max / \min =0.334295082 \pm 0.077233044
$$

Functions for the confidence interval of $95 \%$, liquid state:

$$
\begin{array}{r}
\max / \min =0.246046459-0.000312171 \cdot T \pm 2.20098516 \cdot(0.000557934+ \\
\left.-3.50915 \cdot 10^{-6} \cdot T+5.52305 \cdot 10^{-9} \cdot T^{2}\right)^{1 / 2}
\end{array}
$$

Functions for the confidence interval of $99 \%$, liquid state:

$$
\begin{array}{r}
\max / \min =0.246046459-0.000312171 \cdot T \pm 3.105806516 \cdot(0.000557934+ \\
\left.-3.50915 \cdot 10^{-6} \cdot T+5.52305 \cdot 10^{-9} \cdot T^{2}\right)^{1 / 2}
\end{array}
$$

Appendix A.1.6. Viscosity

Functions for the confidence interval of $95 \%$, liquid state:

$$
\begin{array}{r}
\exp (-5.353284065+2026.013242 / T \pm 2.262157163 \cdot(0.133129577+ \\
\left.\left.-83.58237184 / T+13127.0558 / T^{2}\right)^{1 / 2}\right)
\end{array}
$$

Functions for the confidence interval of $99 \%$, liquid state:

$$
\begin{array}{r}
\exp (-5.353284065+2026.013242 / T \pm 3.249835542 \cdot(0.133129577+ \\
\left.\left.-83.58237184 / T+13127.0558 / T^{2}\right)^{1 / 2}\right)
\end{array}
$$


Appendix A.2. Comparison of Estimated Fit Functions with Functions from Literature
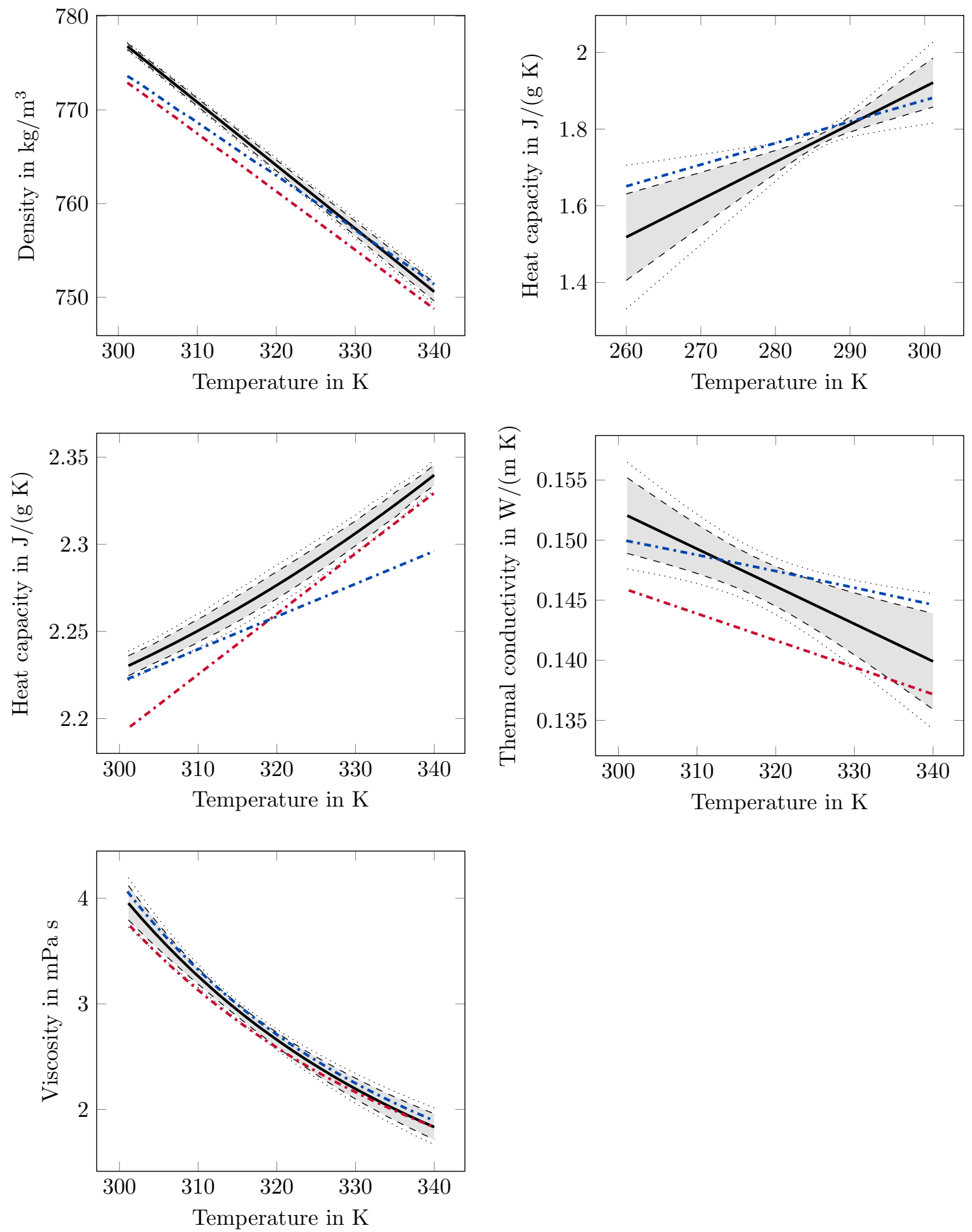

Figure A1. Comparison of the estimated fit functions with functions from literature. The black lines are the estimated fit functions from table 6 (solid line) and the corresponding confidence intervals of $95 \%$ (dashed line) and $99 \%$ (dotted line) from Appendix A.1. The red and blue lines represent the functions from the VDI heat atlas [101] and from Yaws [104], respectively. 


\section{References}

1. Hale, N.W.; Viskanta, R. Photographic observation of the solid-liquid interface motion during melting of a solid heated from an isothermal vertical wall. Lett. Heat Mass Transf. 1978, 5, 329-337, doi:10.1016/0094-4548(78)90041-3. [CrossRef]

2. Hirata, T.; Makino, Y.; Kaneko, Y. Analysis of close-contact melting for octadecane and ice inside isothermally heated horizontal rectangular capsule. Int. J. Heat Mass Transf. 1991, 34, 3097-3106, doi:10.1016/0017-9310(91)90079-T. [CrossRef]

3. Faden, M.; Linhardt, C.; Höhlein, S.; König-Haagen, A.; Brüggemann, D. Velocity field and phase boundary measurements during melting of n-octadecane in a cubical test cell. Int. J. Heat Mass Transf. 2019, 135, 104-114, doi:10.1016/j.ijheatmasstransfer.2019.01.056. [CrossRef]

4. Vogel, J.; Thess, A. Validation of a numerical model with a benchmark experiment for melting governed by natural convection in latent thermal energy storage. Appl. Thermal Eng. 2019, 148, 147-159, doi:10.1016/j.applthermaleng.2018.11.032. [CrossRef]

5. Ho, C.J.; Viskanta, R. Heat Transfer During Melting From an Isothermal Vertical Wall. J. Heat Transf. 1984, 106, 12-19, doi:10.1115/1.3246624. [CrossRef]

6. Rossini, F.D.; American Petroleum Institute Selected Values of Physical and Thermodynamic Properties of Hydrocarbons and Related Compounds: Comprising the Tables of the A.P.I. Research Project 44 Extant As of December 31, 1952; Carnegie Press: Pittsburgh, 1953;

7. Gschwander, S.; Haussmann, T.; Hagelstein, G.; Barreneche, C.; Ferrer, G.; Cabeza, L.; Diarce, G.; Hohenauer, W.; Lager, D.; Rathgeber, C.; et al. Standardization of pcm characterization via DSC. Refrig. Sci. Technol. 2016, 2016, 70-75.

8. Delgado, M.; Gschwander, S.; Lázaro, A.; Peñalosa, C.; Zalba, B. Determining the rheological behavior of octadecane as phase change material: First approach. Thermochim. Acta 2012, 548, 81-87, doi:10.1016/j.tca.2012.09.002. [CrossRef]

9. Tao, Y.B.; Carey, V.P. Effects of PCM thermophysical properties on thermal storage performance of a shell-and-tube latent heat storage unit. Appl. Energy 2016, 179, 203-210, doi:10.1016/j.apenergy.2016.06.140. [CrossRef]

10. Bertrand, O.; Binet, B.; Combeau, H.; Couturier, S.; Delannoy, Y.; Gobin, D.; Lacroix, M.; Le Quéré, P.; Médale, M.; Mencinger, J.; et al. Melting driven by natural convection A comparison exercise: first results. Int. J. Therm. Sci. 1999, 38, 5-26, doi:10.1016/S0035-3159(99)80013-0. [CrossRef]

11. Wang, S.; Faghri, A.; Bergman, T.L. A comprehensive numerical model for melting with natural convection. Int. J. Heat Mass Transf. 2010, 53, 1986-2000, doi:10.1016/j.ijheatmasstransfer.2009.12.057. [CrossRef]

12. Kozak, Y.; Ziskind, G. Novel enthalpy method for modeling of PCM melting accompanied by sinking of the solid phase. Int. J. Heat Mass Transf. 2017, 112, 568-586, doi:10.1016/j.ijheatmasstransfer.2017.04.088. [CrossRef]

13. Assis, E.; Ziskind, G.; Letan, R. Numerical and Experimental Study of Solidification in a Spherical Shell. Int. J. Heat Mass Transf. 2009, 131, 024502, doi:10.1115/1.2993543. [CrossRef]

14. Faden, M.; König-Haagen, A.; Brüggemann, D. An optimum enthalpy approach for melting and solidification with volume change. Energies 2019,12, doi:10.3390/en12050868. [CrossRef]

15. Tan, F.L.; Hosseinizadeh, S.F.; Khodadadi, J.M.; Fan, L. Experimental and computational study of constrained melting of phase change materials (PCM) inside a spherical capsule. Int. J. Heat Mass Transf. 2009, 52, 3464-3472, doi:10.1016/j.ijheatmasstransfer.2009.02.043. [CrossRef]

16. Madruga, S.; Curbelo, J. Dynamic of plumes and scaling during the melting of a Phase Change Material heated from below. Int. J. Heat Mass Transf. 2018, 126, 206-220, doi:10.1016/j.ijheatmasstransfer.2018.05.075. [CrossRef]

17. Galione, P.A.; Lehmkuhl, O.; Rigola, J.; Oliva, A. Fixed-grid numerical modeling of melting and solidification using variable thermo-physical properties-Application to the melting of n-Octadecane inside a spherical capsule. Int. J. Heat Mass Transf. 2015, 86, 721-743, doi:10.1016/j.ijheatmasstransfer.2015.03.033. [CrossRef]

18. Höhne, G.W.H.; Hemminger, W.F.; Flammersheim, H.J. Differential Scanning Calorimetry; Springer: Berlin/Heidelberg, Germany, 2003; doi:10.1007/978-3-662-06710-9. 
19. Qiu, X.; Li, W.; Song, G.; Chu, X.; Tang, G. Microencapsulated n-octadecane with different methylmethacrylate-based copolymer shells as phase change materials for thermal energy storage. Energy 2012, 46, 188-199, doi:10.1016/j.energy.2012.08.037. [CrossRef]

20. Li, W.; Song, G.; Tang, G.; Chu, X.; Ma, S.; Liu, C. Morphology, structure and thermal stability of microencapsulated phase change material with copolymer shell. Energy 2011, 36, 785-791, doi:10.1016/j.energy.2010.12.041. [CrossRef]

21. Tang, F.; Liu, L.; Alva, G.; Jia, Y.; Fang, G. Synthesis and properties of microencapsulated octadecane with silica shell as shape-stabilized thermal energy storage materials. Sol. Energy Mater. Sol. Cells 2017, 160, 1-6, doi:10.1016/j.solmat.2016.10.014. [CrossRef]

22. Bayramoglu, E.Ç. Thermal properties and stability of n-octadecane based composites containing multiwalled carbon nanotubes. Polym. Compos. 2011, 32, 904-909, doi:10.1002/pc.21109. [CrossRef]

23. Jeong, S.G.; Jeon, J.; Lee, J.H.; Kim, S. Optimal preparation of PCM/diatomite composites for enhancing thermal properties. Int. J. Heat Mass Transf. 2013, 62, 711-717, doi:10.1016/j.ijheatmasstransfer.2013.03.043. [CrossRef]

24. Zhang, Z.; Shi, G.; Wang, S.; Fang, X.; Liu, X. Thermal energy storage cement mortar containing n-octadecane/expanded graphite composite phase change material. Renew. Energy 2013, 50, 670-675, doi:10.1016/j.renene.2012.08.024. [CrossRef]

25. Sun, Z.; Kong, W.; Zheng, S.; Frost, R.L. Study on preparation and thermal energy storage properties of binary paraffin blends/opal shape-stabilized phase change materials. Sol. Energy Mater. Sol. Cells 2013, 117, 400-407, doi:10.1016/j.solmat.2013.07.003. [CrossRef]

26. Wang, H.Y.; Lu, S.S. Study on thermal properties of phase change material by an optical DSC system. Appl. Therm. Eng. 2013, 60, 132-136, doi:10.1016/j.applthermaleng.2013.06.055. [CrossRef]

27. Vélez, C.; Khayet, M.; Ortiz de Zárate, J.M. Temperature-dependent thermal properties of solid/liquid phase change even-numbered n-alkanes: N-Hexadecane, n-octadecane and n-eicosane. Appl. Energy 2015, 143, 383-394, doi:10.1016/j.apenergy.2015.01.054. [CrossRef]

28. Ho, C.J.; Gao, J.Y. Preparation and thermophysical properties of nanoparticle-in-paraffin emulsion as phase change material. Int. Commun. Heat Mass Transf. 2009, 36, 467-470, doi:10.1016/j.icheatmasstransfer.2009.01.015. [CrossRef]

29. Li, H.; Liu, X.; Fang, G.Y. Synthesis and characteristics of form-stable n-octadecane/expanded graphite composite phase change materials. Appl. Phys. A 2010, 100, 1143-1148, doi:10.1007/s00339-010-5724-y. [CrossRef]

30. Döğüşcü, D.K.; Kızıl, Ç.; Biçer, A.; Sarı, A.; Alkan, C. Microencapsulated n -alkane eutectics in polystyrene for solar thermal applications. Solar Energy 2018, 160, 32-42. doi:10.1016/j.solener.2017.11.072. [CrossRef]

31. Qiu, X.; Lu, L.; Wang, J.; Tang, G.; Song, G. Fabrication, thermal properties and thermal stabilities of microencapsulated n-alkane with poly(lauryl methacrylate) as shell. Thermochim. Acta 2015, 620, 10-17, doi:10.1016/j.tca.2015.10.001. [CrossRef]

32. Jeon, J.; Jeong, S.G.; Lee, J.H.; Seo, J.; Kim, S. High thermal performance composite PCMs loading xGnP for application to building using radiant floor heating system. Sol. Energy Mater. Sol. Cells 2012, 101, 51-56, doi:10.1016/j.solmat.2012.02.028. [CrossRef]

33. Zhang, G.H.; Bon, S.; Zhao, C.Y. Synthesis, characterization and thermal properties of novel nanoencapsulated phase change materials for thermal energy storage. Solar Energy 2012, 86, 1149-1154, doi:10.1016/j.solener.2012.01.003. [CrossRef]

34. Shan, X.L.; Wang, J.P.; Zhang, X.X.; Wang, X.C. Formaldehyde-free and thermal resistant microcapsules containing n-octadecane. Thermochim. Acta 2009, 494, 104-109, doi:10.1016/j.tca.2009.04.026. [CrossRef]

35. Chaiyasat, A.; Waree, C.; Songkhamrod, K.; Sirithip, P.; Voranuch, V.; Chaiyasat, P. Preparation of polydivinylbenzene/natural rubber capsule encapsulating octadecane: Influence of natural rubber molecular weight and content. Express Polym. Lett. 2012, 6, 70-77, doi:10.3144/expresspolymlett.2012.8. [CrossRef]

36. Chung, O.; Jeong, S.G.; Kim, S. Preparation of energy efficient paraffinic PCMs/expanded vermiculite and perlite composites for energy saving in buildings. Sol. Energy Mater. Sol. Cells 2015, 137, 107-112, doi:10.1016/j.solmat.2014.11.001. [CrossRef]

37. He, F.; Wang, X.; Wu, D. New approach for sol-gel synthesis of microencapsulated n-octadecane phase change material with silica wall using sodium silicate precursor. Energy 2014, 67, 223-233, doi:10.1016/j.energy.2013.11.088. [CrossRef] 
38. Yu, S.; Wang, X.; Wu, D. Microencapsulation of n-octadecane phase change material with calcium carbonate shell for enhancement of thermal conductivity and serving durability: Synthesis, microstructure, and performance evaluation. Appl. Energy 2014, 114, 632-643, doi:10.1016/j.apenergy.2013.10.029. [CrossRef]

39. Zhang, H.; Xu, Q.; Zhao, Z.; Zhang, J.; Sun, Y.; Sun, L.; Xu, F.; Sawada, Y. Preparation and thermal performance of gypsum boards incorporated with microencapsulated phase change materials for thermal regulation. Sol. Energy Mater. Sol. Cells 2012, 102, 93-102, doi:10.1016/j.solmat.2012.03.020. [CrossRef]

40. Babich, M.W.; Hwang, S.W.; Mounts, R.D. The search for novel energy storage materials using differential scanning calorimetry. Thermochim. Acta 1992, 210, 83-88, doi:10.1016/0040-6031(92)80279-6. [CrossRef]

41. Zhu, Y.; Liang, S.; Wang, H.; Zhang, K.; Jia, X.; Tian, C.; Zhou, Y.; Wang, J. Morphological control and thermal properties of nanoencapsulated $n$-octadecane phase change material with organosilica shell materials. Energy Convers. Manag. 2016, 119, 151-162, doi:10.1016/j.enconman.2016.04.049. [CrossRef]

42. Wei, D.; Han, S.; Wang, B. Solid-liquid phase equilibrium study of binary mixtures of n-octadecane with capric, and lauric acid as phase change materials (PCMs). Fluid Phase Equilib. 2014, 373, 84-88, doi:10.1016/j.fluid.2014.04.020. [CrossRef]

43. Chang, S.S.; Maurey, J.R.; Pummer, W.J. Solubilities of two n-alkanes in various solvents. J. Chem. Eng. Data 1983, 28, 187-189, doi:10.1021/je00032a017. [CrossRef]

44. Kolesnikov, S.; Syunyaev, Z. Calorimetric study of the phase-transitions of solid hydrocarbons. 1. phase-transitions in the melting and crystallization of n-c18h38 and n-c20h42. J. Appl. Chem. USSR 1985, 58, 2097-2101.

45. Huang, D.; Simon, S.L.; McKenna, G.B. Chain length dependence of the thermodynamic properties of linear and cyclic alkanes and polymers. J. Chem. Phys. 2005, 122, 84907, doi:10.1063/1.1852453. [CrossRef] [PubMed]

46. Djordjevic, N.M.; Laub, R.J. Mutual solubilities of components of binary blends of n-octadecane, DI-n-octyl ether, and N,N-dioctylamine. Thermochim. Acta 1986, 107, 227-238, doi:10.1016/0040-6031(86)85050-X. [CrossRef]

47. Fonseca, J.M.; Gushterov, N.; Dohrn, R. Vapour pressures of selected organic compounds down to $1 \mathrm{mPa}$, using mass-loss Knudsen effusion method. J. Chem. Thermodyn. 2014, 73, 148-155, doi:10.1016/j.jct.2013.11.038. [CrossRef]

48. Boudouh, I.; Hafsaoui, S.L.; Mahmoud, R.; Barkat, D. Measurement and prediction of solid-liquid phase equilibria for systems containing biphenyl in binary solution with long-chain n-alkanes. J. Therm. Anal. Calorim. 2016, 125, 793-801, doi:10.1007/s10973-016-5407-9. [CrossRef]

49. Mondieig, D.; Rajabalee, F.; Metivaud, V.; Oonk, H.A.J.; Cuevas-Diarte, M.A. n-Alkane Binary Molecular Alloys. Chem. Mater. 2004, 16, 786-798, doi:10.1021/cm031169p. [CrossRef]

50. Robles, L.; Mondieig, D.; Haget, Y.; Cuevas-Diarte, M.A.; Alcobe, X. Non Isomorphism and Miscibility in The Solid State: Determination of The Equilibrium Phase Diagram n-Octadecane C 18 H 38 + n-Nonadecane C 19 H 40. Mol. Cryst. Liquid Cryst. Sci. Technol. Sect. A 1996, 281, 279-290, doi:10.1080/10587259608042251. [CrossRef]

51. Wei, D.; Zhang, X.; Li, H. Solid-liquid phase equilibrium study of n-octadecane+lauryl alcohol binary mixtures. J. Chem. Thermodyn. 2013, 60, 94-97, doi:10.1016/j.jct.2013.01.019. [CrossRef]

52. Schaerer, A.A.; Busso, C.J.; Smith, A.E.; Skinner, L.B. Properties of Pure Normal Alkanes in the C 17 to C 36 Range. J. Am. Chem. Soc. 1955, 77, 2017-2019, doi:10.1021/ja01612a097. [CrossRef]

53. Parks, G.S.; Moore, G.E.; Renquist, M.L.; Naylor, B.F.; McClaine, L.A.; Fujii, P.S.; Hatton, J.A. Thermal Data on Organic Compounds. XXV. Some Heat Capacity, Entropy and Free Energy Data for Nine Hydrocarbons of High Molecular Weight. J. Am. Chem. Soc. 1949, 71, 3386-3389. [CrossRef]

54. Messerly, J.F.; Guthrie, G.B., Jr.; Todd, S.S.; Finke, H.L. Low-temperature thermal data for pentane, n-heptadecane, and n-octadecane. Revised thermodynamic functions for the n-alkanes, C5-C18. J. Chem. Eng. Data 1967, 1967, 338-346. [CrossRef]

55. Meyer, E.F.; Meyer, M.C. Solid-liquid phase behavior of nonadecylcyclohexane and nonadecylbenzene. J. Chem. Eng. Data 1983, 28, 148-150, doi:10.1021/je00032a003. [CrossRef]

56. Ksiażczak, A. Vapour pressures of binary three-phase (solid + liquid + vapour) mixtures IV. Melting temperatures of the solid phases of n-octadecane and of n-nonadecane. J. Chem. Thermodyn. 1989, 21, 1231-1236, doi:10.1016/0021-9614(89)90111-0. [CrossRef] 
57. Carey, P.C.; Smith, J.C. 92. Higher aliphatic compounds. Part III. The preparation of paraffins. J. Chem. Soc. 1933, 346, doi:10.1039/JR9330000346. [CrossRef]

58. Domańska, U.; Łachwa, J.; Morawski, P.; Malanowski, S.K. Phase Equilibria and Volumetric Properties in Binary Mixtures Containing Branched Chain Ethers (Methyl 1,1-Dimethylethyl Ether or Ethyl 1,1-Dimethylethyl Ether or Methyl 1,1-Dimethylpropyl Ether or Ethyl 1,1-Dimethylpropyl Ether). J. Chem. Eng. Data 1999, 44, 974-984, doi:10.1021/je9900124. [CrossRef]

59. Levene, P.; West, C.; van der Scheer, J. The preparation and melting points of the higher aliphatic hydrocarbons. Stud. Repr. 1915, 22, 239.

60. Parks, G.S.; West, T.J.; Naylor, B.F.; Fujii, P.S.; McClaine, L.A. Thermal Data on Organic Compounds. XXIII. Modern Combustion Data for Fourteen Hydrocarbons and Five Polyhydroxy Alcohols. J. Am. Chem. Soc. 1946, 68, 2524-2527, doi:10.1021/ja01216a028. [CrossRef]

61. Krafft, F. Ueber neunzehn höhere Normalparaffine Cn H2n +2 und ein einfaches Volumgesetz für den tropfbar flüssigen Zustand. II. Berichte der deutschen chemischen Gesellschaft 1882, 15, 1711-1727, doi:10.1002/cber.18820150259. [CrossRef]

62. Seyer, W.F.; Patterson, R.F.; Keays, J.L. The Density and Transition Points of the n-Paraffin Hydrocarbons. J. Am. Chem. Soc. 1944, 66, 179-182, doi:10.1021/ja01230a004. [CrossRef]

63. Dover, M.V.; Hensley, W.A. Properties of 1-Octadecene, n-Octadecane, and Di-m-tolylethane. Ind. Eng. Chem. 1935, 27, 337-339, doi:10.1021/ie50303a023. [CrossRef]

64. van Hook, A.; Silver, L. Premelting Anomalies of Some Long Chain Normal Paraffin Hydrocarbons. J. Chem. Phys. 1942, 10, 686-690, doi:10.1063/1.1723645. [CrossRef]

65. Cutler, W.G.; McMickle, R.H.; Webb, W.; Schiessler, R.W. Study of the Compressions of Several High Molecular Weight Hydrocarbons. J. Chem. Phys. 1958, 29, 727-740, doi:10.1063/1.1744583. [CrossRef]

66. Nelson, R.R.; Webb, W.; Dixon, J.A. First-Order Phase Transitions of Six Normal Paraffins at Elevated Pressures. J. Chem. Phys. 1960, 33, 1756-1764, doi:10.1063/1.1731498. [CrossRef]

67. Shlosinger, A.P.; Bentilla, E.W. Research and Development Study on Thermal Control by Use of Fusible Materials. Available online: https://ntrs.nasa.gov/archive/nasa/casi.ntrs.nasa.gov/19660017401.pdf (accessed on 16 January 2019).

68. Findenegg, G.H. Dichte und Ausdehnungskoeffizient einiger flüssiger Alkane. Monatshefte für Chemie 1970, 101, 1081-1088, doi:10.1007/BF00908551. [CrossRef]

69. Espeau, P.; Céolin, R. A simple method to determine the specific volumes of liquids and melts as a function of the temperature. Thermochim. Acta 2006, 445, 32-35, doi:10.1016/j.tca.2006.04.001. [CrossRef]

70. Caudwell, D.R.; Trusler, J.P.M.; Vesovic, V.; Wakeham, W.A. The Viscosity and Density of n-Dodecane and n-Octadecane at Pressures up to $200 \mathrm{MPa}$ and Temperatures up to $473 \mathrm{~K}$. Int. J. Thermophys. 2004, 25, 1339-1352, doi:10.1007/s10765-004-5742-0. [CrossRef]

71. Graaf, G.H.; Smit, H.J.; Stamhuis, E.J.; Beenackers, A.A.C.M. Gas-liquid solubilities of the methanol synthesis components in various solvents. J. Chem. Eng. Data 1992, 37, 146-158, doi:10.1021/je00006a004. [CrossRef]

72. McKinney, J.W. THE CONSTITUTION OF KEROGEN. J. Am. Chem. Soc. 1924, 46, 968-979, doi:10.1021/ja01669a020. [CrossRef]

73. Würflinger, A.; Schneider, G.M. Differential Thermal Analysis under High Pressures II: Investigation of the Rotational Transition of Several n-Alkanes. Berichte der Bunsengesellschaft für physikalische Chemie 1973, 77, 121-128, doi:10.1002/bbpc.19730770213. [CrossRef]

74. Müller, A.; Lonsdale, K. The low-temperature form of C 18 H 38. Acta Crystallogr. 1948, 1, 129-131, doi:10.1107/S0365110X4800034X. [CrossRef]

75. Dutour, S.; Daridon, J.L.; Lagourette, B. Pressure and Temperature Dependence of the Speed of Sound and Related Properties in Normal Octadecane and Nonadecane. Int. J. Thermophys. 2000, 21, 173-184, doi:10.1023/A:1006665006643. [CrossRef]

76. Höhne, G.W.H. Transitions of n-Alkanes Above the Melting Point. Polym. Bull. 1981, 1981, 41-46. [CrossRef]

77. Durupt, N.; Aoulmi, A.; Bouroukba, M.; Rogalski, M. Heat capacities of liquid long-chain alkanes. Thermochim. Acta 1996, 274, 73-80, doi:10.1016/0040-6031(95)02255-4. [CrossRef]

78. van Miltenburg, J.C. Fitting the heat capacity of liquid n-alkanes: new measurements of n-heptadecane and n-octadecane. Thermochim. Acta 2000, 343, 57-62. [CrossRef]

79. Czichos, H.; Saito, T.; Smith, L. Springer Handbook of Materials Measurement Methods; Springer handbooks; Springer: Berlin, Germany, 2006; doi:10.1007/978-3-540-30300-8. 
80. Irby, R.G.; Parsons, J.R.; Keshock, E.G. An investigation of the thermal transport properties of octadecane, a material used in thermal energy storage systems. In Thermal Conductivity 19; Yarbrough, D.W., Ed.; Plenum Press: New York, NY, USA, 1988.

81. Harish, S.; Orejon, D.; Takata, Y.; Kohno, M. Thermal conductivity enhancement of lauric acid phase change nanocomposite with graphene nanoplatelets. Appl. Therm. Eng. 2015, 80, 205-211, doi:10.1016/j.applthermaleng.2015.01.056. [CrossRef]

82. Wu, Y.; Yan, X.; Meng, P.; Sun, P.; Cheng, G.; Zheng, R. Carbon black/octadecane composites for room temperature electrical and thermal regulation. Carbon 2015, 94, 417-423, doi:10.1016/j.carbon.2015.06.037. [CrossRef]

83. Khadiran, T.; Hussein, M.Z.; Zainal, Z.; Rusli, R. Shape-stabilised n-octadecane/activated carbon nanocomposite phase change material for thermal energy storage. J. Taiwan Inst. Chem. Eng. 2015, 55, 189-197, doi:10.1016/j.jtice.2015.03.028. [CrossRef]

84. Águila V, B.; Vasco, D.A.; Galvez P, P.; Zapata, P.A. Effect of temperature and CuO-nanoparticle concentration on the thermal conductivity and viscosity of an organic phase-change material. Int. J. Heat Mass Transf. 2018, 120, 1009-1019, doi:10.1016/j.ijheatmasstransfer.2017.12.106. [CrossRef]

85. Motahar, S.; Nikkam, N.; Alemrajabi, A.A.; Khodabandeh, R.; Toprak, M.S.; Muhammed, M. A novel phase change material containing mesoporous silica nanoparticles for thermal storage: A study on thermal conductivity and viscosity. Int. Commun. Heat Mass Transf. 2014, 56, 114-120, doi:10.1016/j.icheatmasstransfer.2014.06.005. [CrossRef]

86. Motahar, S.; Alemrajabi, A.A.; Khodabandeh, R. Enhanced thermal conductivity of n-octadecane containing carbon-based nanomaterials. Heat Mass Transf. 2016, 52, 1621-1631, doi:10.1007/s00231-015-1678-0. [CrossRef]

87. Sakiadis, B.C.; Coates, J. Studies of thermal conductivity of liquids: Part III. AIChE J. 1957, 3, 121-126, doi:10.1002/aic.690030120. [CrossRef]

88. Powell, R.W.; Challoner, A.R.; Seyer, W.F. Correspondence. Measurement of Thermal Conductivity of n-Octadecane. Ind. Eng. Chem. 1961, 53, 581-582, doi:10.1021/ie50619a033. [CrossRef]

89. Ziebland, H.; Patient, J.E. Communication. Thermal Conductivity of n-Octadecane. New Measurements and a Critical Appraisal of the Article by Sutherland, Davis, and Seyer. J. Chem. Eng. Data 1962, 7, 530-531, doi:10.1021/je60015a026. [CrossRef]

90. Griggs, E.I.; Yarbrough, D.W. Thermal conductivity of solid unbranched alkanes from n-hexadecane to n-eicosane. In Proceedings of the 14th Southeastern Seminar on Thermal Sciences, Raleigh, NC, USA, 6-7 April 1978; pp. 256-267.

91. Yarbrough, D.W.; Kuan, C.N. The Thermal Conductivity of Solid N-Eicosane, N-Octadecane, N-Heptadecane, N-Pentadecane, and N-Tetradecane. In Thermal Conductivity 17; Hust, J.G., Ed.; Springer: Boston, MA, USA, 1983; pp. 265-274, doi:10.1007/978-1-4899-5436-7\{\_\}25.

92. Mustafaev, R.A. Thermal conductivity of higher saturated n-hydrocarbons over wide ranges of temperature and pressure. J. Eng. Phys. 1973, 24, 465-469. [CrossRef]

93. Rastorguev, Y.L.; Bogatov, G.F. Thermal conductivity of n-heptadecane and n-octadecane at high pressures and temperatures. Chem. Technol. Fuels Oils 1972, 8, 176-179, doi:10.1007/BF00730290. [CrossRef]

94. Holmen, R.; Lamvik, M.; Meldus, O. Measurements of the Thermal Conductivities of Solid and Liquid Unbranched Alkanes in the C16-to-C19 Range During Phase Transition. Int. J. Thermophys. 2002, 2002, $27-39$. [CrossRef]

95. C-Therm Technologies Ltd. TCi Thermal Conductivity Analyzer. Available online: https://ctherm.com/ products/tci_thermal_conductivity/specifications/ (accessed on 18 October 2018).

96. EKO Instruments B.V. HC-10 Thermal Conductivity Tester. Available online: https://eko-eu.com/ products / material-analysis/thermal-conductivity-testers/hc-10-thermal-conductivity-tester (accessed on 18 October 2018).

97. Rastorguev, Y.L.; Grigor'ev, B.A.; Bogatov, G.F. Experimental study of the thermal conductivity of toluene at high pressures. J. Eng. Phys. 1969, 17, 1370-1376, doi:10.1007/BF00828314. [CrossRef]

98. Delgado, M.; Lázaro, A.; Biedenbach, M.; Gamisch, S.; Gschwander, S.; Höhlein, S.; König-Haagen, A.; Brüggemann, D. Intercomparative tests on viscosity measurements of phase change materials. Thermochim. Acta 2018, 668, 159-168, doi:10.1016/j.tca.2018.08.017. [CrossRef] 
99. Hogenboom, D.L.; Webb, W.; Dixon, J.A. Viscosity of Several Liquid Hydrocarbons as a Function of Temperature, Pressure, and Free Volume. J. Chem. Phys. 1967, 46, 2586-2598, doi:10.1063/1.1841088. [CrossRef]

100. Ducoulombier, D.; Zhou, H.; Boned, C.; Peyrelasse, J.; Saint-Guirons, H.; Xans, P. Pressure (1-1000 bars) and temperature (20-100.degree.C) dependence of the viscosity of liquid hydrocarbons. J. Phys. Chem. 1986, 90, 1692-1700, doi:10.1021/j100399a047. [CrossRef]

101. Verein deutscher Ingenieure. VDI-Wärmeatlas, 11st ed.; Springer: Berlin/Heidelberg, Germany, 2013; doi:10.1007/978-3-642-19981-3. [CrossRef]

102. Cameron, A.C.; Miller, D.L. A Practitioner's Guide to Cluster-Robust Inference. J. Hum. Resour. 2015, 50,317-372, doi:10.3368/jhr.50.2.317. [CrossRef]

103. Hemberger, F.; Brütting, M.; Göbel, A.; Vidi, S.; Ebert, H.P. Determination of thermal diffusivity of different crystal structures of phase change materials by means of the flash method. In Proceedings of the 34th International Thermal Conductivity Conference (ITCC), Wilmington, DE, USA, 17-20 June 2019.

104. Yaws, C.L. Yaws' Handbook of Thermodynamic and Physical Properties of Chemical Compounds: Physical, Thermodynamic and Transport Properties for 5.000 Organic Chemical Compounds; [Interactive Table], electronic ed.; Knovel: Norwich, NY, USA, 2004.

(C) 2019 by the authors. Licensee MDPI, Basel, Switzerland. This article is an open access article distributed under the terms and conditions of the Creative Commons Attribution (CC BY) license (http://creativecommons.org/licenses/by/4.0/). 